\title{
The importance of triazole scaffold in the development of anticonvulsant agents
}

Adile Ayati $^{a}$, Saeed Emami ${ }^{b, *}$, Alireza Foroumadi ${ }^{a, * *}$

${ }^{a}$ Department of Medicinal Chemistry, Faculty of Pharmacy and Pharmaceutical Sciences Research Center, Tehran University of Medical Sciences, Tehran 14176, Iran

${ }^{b}$ Department of Medicinal Chemistry and Pharmaceutical Sciences Research Center, Faculty of Pharmacy, Mazandaran University of Medical Sciences, Sari, Iran

\begin{abstract}
Epilepsy is one of the most important neurological disorders with high prevalence worldwide. Many epileptic patients are not completely treated with available drugs and need multiple therapies. Also, many antiepileptic drugs have shown unwanted side effects and drug interactions. Therefore there are continuing interests to find new anticonvulsant drugs. Triazole ring has been found in the structure of many compounds with diverse biological effects. Due to the success of several triazole-containing drugs that entered the pharmaceutical market as CNS-active drugs, this class of heterocyclic compounds has great importance for discovery and development of new anticonvulsant drugs. In this article, we have tried to summarize the latest efforts which have been made in the design and development of triazole-derived anticonvulsant agents.
\end{abstract}

Keywords: Anticonvulsant agents; Antiepileptic drugs; Epilepsy; 1,2,4-triazole; Fused triazoles

* Corresponding author.

Tel: 9811 33543082; Fax: 9811 33543084.E-mail: sd_emami@yahoo.com (S. Emami)

** Corresponding author.

Tel.:'98 21 66406757; Fax:998 21 66461178. E-mail: aforoumadi@yahoo.com (A. Foroumadi) 


\section{Introduction}

Epilepsy is a central nervous system (CNS) disorder characterized by rapid and excessive electrical neuronal discharges [1]. The imbalance of excitatory and inhibitory processes within neurons of the brain leads to uncontrolled convulsions and lack of consciousness [2]. The main strategy for epilepsy treatment is pharmacotherapy with antiepileptic or anticonvulsant drugs [3]. In general, the antiepileptic drugs act through several ways: (i) restriction of excitatory processes by blocking excitatory amino acid receptors and/or voltage activated sodium channels, (ii) enhancement of inhibitory processes by potentiating the activity of the $\gamma$-aminobutyric acid (GABA) as brain's inhibitory neurotransmitter, and (iii) stabilization of thalamic neurons through inhibition of T-type calcium channels [4].

Based on the epidemiological studies, at least 50 million people worldwide suffer from epilepsy while in less than $70 \%$ of the patients seizures are completely controlled by using available antiepileptic drugs [5]. In some cases monotherapy is not sufficient and polytherapy with multiple drugs is required for successful treatment [6]. Also, many epileptic patients suffer from side effects of anticonvulsant agents due to the long-term medication [7]. In recent years, investigations are continued to discover new anticonvulsant drugs and several new drugs such as felbamate, gabapentin, lacosamide, eslicarbazepine acetate, lamotrigine, oxcarbazepine, pregabaline, levetiracetam, retigabine, stiripentol, rufinamide, tiagabine, zonisamide, vigabatrine and topiramate entered to the market $[8,9]$. However, due to the low efficiency, drug resistance and toxicity of existing drugs, new attempts in this area are still necessary [10].

The search for new anticonvulsant drugs has traditionally been focused on compounds that suppress seizures in a symptomatic fashion. Several animal models including maximum electroshock (MES), pentylenetetrazole (PTZ), thiosemicarbazide (TSZ), isoniazid (INH), 3-mercaptopropionic acid (3MPA) and strychnine (STR)-induced seizures methods were widely used in the preclinical discovery and development of novel anticonvulsant agents [1113]. However, the MES and PTZ-induced seizures tests are the most widely used animal models of epilepsy to characterize the anticonvulsant activity [14].

1,2,4-Triazole is a five member heterocycle with two carbons and three nitrogen atoms and molecular formula $\mathrm{C}_{2} \mathrm{H}_{3} \mathrm{~N}_{3}$. This compound is a basic aromatic heterocycle with two different tautomeric forms (Fig. 1) [15]. It should be noted that three different tautomers $\mathbf{A}, \mathbf{B}$ and $\mathbf{C}$ 
(N1-H, N2-H, and N4-H, respectively) are possible for the substituted 1,2,4-triazoles (Fig. 2) $[16]$.

A literature survey revealed that triazole derivatives possess variety of biological properties including antimicrobial [18], antifungal [19-21], antileishmanial [22], antiviral [23], antitubercular [24], anticancer [25,26], antioxidant [27], anticholinesterase [28], antiinflammatory [29,30], antidepressant, antianxiety and anticonvulsant activities [31]. In particular, many well-known CNS active drugs such as loreclezole (1), rizatriptan (2), estazolam (3), alprazolam (4), etizolam (5), triazolam (6), rilmazafone (7), nefazodone (8) and trazodone (9) are triazole derivatives (Fig. 3).

Due to the importance of triazole scaffold in the discovery and development of CNS active drugs, we intended to review triazole derivatives which have been recently synthesized and had notable anticonvulsant activity. These derivatives have been classified into the following structural categories: $N$-(arylalkyl)triazoles, $N$-aryltriazoles, 3,5-disubstituted-4H-1,2,4triazoles, triazolones and triazole thiones, and fused-triazoles.

\section{2. $N$-(Arylalkyl)triazoles}

$N$-(Arylalkyl)azoles are a distinct class of anticonvulsant agents exemplified by imidazole analogs nafimidone (10) and denzimol (11, Fig 4) [32,33]. It seems that these compounds with lipophilic aryl ring linked by an alkylene bridge to nitrogen of azole could be better penetrating to the blood-brain barrier. Based on the structure-activity relationship studies, the presence of oxygen functional group (such as carbonyl, carbamoyl, ethylene dioxy, methoxy, acyloxy, and hydroxy substituents) on the alkylene bridge can improve their anticonvulsant potencies [34,35]. The 1,2,4-triazole analog loreclezole (1, Fig 4) is a representative anticonvulsant with broad-spectrum activity [36,37]. In the loreclezole structure, the lipophilic 2,4-dichlorophenyl moiety is connected to the triazole ring via a two carbons linker containing electronegative chlorine atom. In vivo studies have been suggested that loreclezole acts on the neuromodulatory site within the $\mathrm{GABA}_{\mathrm{A}}$ receptor complex, which is unlikely to be a benzodiazepine receptor [36]. Indeed, loreclezole is a positive modulator of $\mathrm{GABA}_{\mathrm{A}}$ receptor with selectivity for $\beta 2 / \beta 3$ - over $\beta 1$-subunit [37,38].

A series of (arylalkyl)azoles namely [1-(2-naphthyl)-2-(1,2,4-triazol-1-yl)ethanone oximes 12 and oxime ethers 13 (Fig 4) were designed and synthesized by Karakurt et al. as nafimidone 
analogs. The synthesized compounds were evaluated by MES and PTZ tests in mice and rats. Based on the anticonvulsant and neurotoxicity screening data, compounds with small alkyl groups such as methyl, ethyl, propyl and allyl showed better activity in the dose of $100 \mathrm{mg}$ $/ \mathrm{kg}$ respect to the compounds with larger substitutions like benzyl and substituted benzyl groups [39].

In order to find new anticonvulsant agents, a series of conformationally constrained analogs of (arylalkyl)azoles including triazol-1-ylchromanones 14 and triazol-4-ylchromanones 15 (Fig. 5) were evaluated by our group. The seizure latency and protective effect of target compounds were evaluated at the dose of $5 \mathrm{mg} / \mathrm{kg}$ against PTZ-induced lethal convulsions in mice. Among them, the prototype compound $\mathbf{1 4}$ with $\mathrm{X}=\mathrm{O}$ and $\mathrm{R}=\mathrm{R}_{1}=\mathrm{H}$ exhibited significant action in delaying seizures as well as effective protection against PTZ-induced convulsions in mice. The seizure latency for this compound at the dose of $5 \mathrm{mg} / \mathrm{kg}$ was 22 min. While the standard drug valproate showed about 16 min seizure latency at the dose of $150 \mathrm{mg} / \mathrm{kg}$ [40]. In the next study, the anticonvulsive and antiepileptogenic properties of the prototype compound $14\left(\mathrm{X}=\mathrm{O}\right.$ and $\left.\mathrm{R}=\mathrm{R}_{1}=\mathrm{H}\right)$ were assessed by using two distinct pharmacological models; lithium-pilocarpine induced seizure and PTZ-induced kindling. In contrast to the potent activity of the compound in the acute model of PTZ test, this compound showed limited activity in PTZ-induced kindling model. These findings are not surprising due to the fundamentally difference of PTZ-induced lethal test and PTZ-kindling model. However, the selected compound was effective in the lithium-pilocarpine model of epilepsy. Administration of the compound at the dose of $10 \mathrm{mg} / \mathrm{kg}, 30 \mathrm{~min}$ before pilocarpine effectively delayed the onset of seizures (49\%) [41].

Two sets of (arylalkyl)azoles 16 and 17 (Fig. 6) containing 1,2,4-oxadiazole as a linker were prepared by Lankau et al., and tested for their anticonvulsant activity in rats by using MES and PTZ tests. Based on the results, 5-phenyl-3-(1H-1,2,4-triazol-1-ylmethyl)-1,2,4oxadiazole showed the most promising anticonvulsant activity in both models $\left(\mathrm{ED}_{50}=25.5\right.$ $\mathrm{mg} / \mathrm{kg}$ in PTZ and $\mathrm{ED}_{50}=14.6 \mathrm{mg} / \mathrm{kg}$ in MES). The rotarod test was used to evaluate the neurotoxicity of the title compound. The obtained $\mathrm{TD}_{50}$ was $335 \mathrm{mg} / \mathrm{kg}$. Lankau et al. suggested that the oxadiazole-based (arylalkyl)azoles act as selective GABA potentiating agents with no interaction to the benzodiazepine binding site [42].

Recently, our group have synthesized some 1-[(2-arylthiazol-4-yl)methyl]azoles including triazole derivatives as thiazole-incorporated (arylalkyl)azoles. Anticonvulsant activity 
evaluation of the title compounds by using two models, PTZ and MES in mice revealed that 1-[(2-phenylthiazol-4-yl)methyl]-1H-1,2,4-triazole (18) and its 4-chlorophenyl analog 19 (Fig. 6) had the highest anticonvulsant activity. In particular, compound 19 showed 100\% protection at the dose of $100 \mathrm{mg} / \mathrm{kg}$ against both PTZ- and MES-induced seizures [43].

\section{3. $N$-Aryltriazoles}

Chen et al. described the synthesis of 4-alkoxylphenyl-3-ethyl-4H-1,2,4-triazoles by using one-pot, three-component reaction of primary amines, acyl hydrazines and dimethylformamide dimethyl acetal. The target compounds were evaluated for their anticonvulsant activities in the MES test. Two compounds, 3-ethyl-4-(4-heptyloxyphenyl)4H-1,2,4-triazole (20) and 3-ethyl-4-(4-octyloxyphenyl)-4H-1,2,4-triazole (21, Fig. 7) with $\mathrm{ED}_{50}$ values of $8.3 \mathrm{mg} / \mathrm{kg}$ and $8.8 \mathrm{mg} / \mathrm{kg}$ had higher activity than standard drug phenytoin. The rotarod neurotoxicity test revealed that compound $\mathbf{2 1}$ had better protective index (PI= $\left.\mathrm{TD}_{50} / \mathrm{ED}_{50}=9.3\right)$ which was much greater than that of phenytoin $(\mathrm{PI}=6.9)$. In order to explain the possible mechanism of action, the compound 21 was tested by PTZ, INH, TSZ, 3MPA and STR-induced seizures methods. It was postulated that this type of compounds acts through GABAergic neurotransmission and activate glutamate decarboxylase (GAD) or inhibit (GABA)- $\alpha$-oxoglutarate aminotransferase (GABA-T) in the brain [44].

Recently, a series of 3-alkoxy-4-(4-(hexyloxy/heptyloxy) phenyl)-4H-1,2,4-triazoles 22 (Fig. 7) were designed and synthesized by Fang et al. The results of MES test revealed that the size of the alkyl chain plays an important role in anticonvulsant activity. The 4-(4hexyloxyphenyl)-4H-1,2,4-triazole derivative bearing a 3-heptyloxy residue $\left(\mathrm{R}_{1}=n-\mathrm{C}_{6} \mathrm{H}_{13}\right.$, $\mathrm{R}_{2}=n-\mathrm{C}_{7} \mathrm{H}_{15}$ ) was the most potent compound. Its $\mathrm{ED}_{50}$ value in MES test was $37.3 \mathrm{mg} / \mathrm{kg}$. Based on rotarod neurotoxicity assay, this compound with protective index of 11.3 had the lowest toxicity. The anti-seizure efficacy of the prototype compound against convulsions induced by PTZ, 3MPA and bicuculline (BIC) were also established [45].

Some quinolone derivatives showed promising anticonvulsant [46] and antidepressant activities [47]. Accordingly, Deng et al. incorporated the triazole motif to the quinolones to obtain compounds 23 (Fig. 7) with both anticonvulsant and antidepressant properties. The anticonvulsant and antidepressant screening of the synthesized compounds were performed using the MES and forced swimming test (FST). The obtained results indicated that 
compounds with chloro- and fluorobenzyl substitutions had better antidepressant activities in comparison to fluoxetine as the reference drug. On the other hand, compounds with $\mathrm{R}=$ pentyl or hexyl showed $100 \%$ protection against MES-induced seizures at the dose of 100 $\mathrm{mg} / \mathrm{kg}$. The neurotoxicity rotarod test indicated that these compounds had no toxic effect at the same dose [48].

In a study by Wang et al., several purine-based triazoles were synthesized and tested by using MES and PTZ tests in mice. The results indicated that 9-decyl-6-(1H-1,2,4-triazol-1-yl)-9Hpurine (24, Fig. 7) with $\mathrm{ED}_{50}$ of $23.4 \mathrm{mg} / \mathrm{kg}$ had comparable activity and higher safety than carbamazepine as the standard drug. Also, compound $\mathbf{2 4}$ was effective anticonvulsant in MES model of epilepsy when administrated orally in mice $\left(\mathrm{ED}_{50}=39.4 \mathrm{mg} / \mathrm{kg}\right)$. The SAR studies revealed that the replacement of triazole ring with other heterocycles such as imidazole, methylimidazole, and pyrazole results in compounds with decreased activity and higher neurotoxicity. Moreover, when the triazolyl moiety was replaced by 1,2,4-triazol-3-ylthio group, the obtained compounds showed no activity [49].

\section{3,5-Disubstituted-4H-1,2,4-triazoles}

Some 3-(2-phenoxy)phenyl-4H-1,2,4-triazoles were designed and synthesized as simple nonrigid analog of estazolam (3), a well known benzodiazepine agonist. Pharmacological evaluation of the compounds in mice revealed that the presence of amino group at C-5 of triazole ring improves the anticonvulsant activity. The 2-chlorophenoxy derivative 25 (Fig. 8) was the most potent compound $\left(\mathrm{ED}_{50}=12.0 \mathrm{mg} / \mathrm{kg}\right.$, ip). The $\mathrm{ED}_{50}$ value of compound 25 was significantly reduced by flumazenil $(10 \mathrm{mg} / \mathrm{kg})$, indicating the involvement of benzodiazepine receptors in the anticonvulsant activity [50].

In another work, a series of 5-(phenoxyphenyl)-3-amino-4H-1,2,4-triazoles were synthesized by the condensation reaction of 4-chloro-2-phenoxybenzoyl chloride and aminoguanidine hydrogen carbonate in dry pyridine. The biological evaluation of target compounds by PTZ method in mice revealed that 3-amino-5-[4-chloro-2-(2-fluorophenoxy)phenyl]-4H-1,2,4triazole 26 (Fig. 8), showed much better anticonvulsant activity $\left(\mathrm{ED}_{50}=1.4 \mathrm{mg} / \mathrm{kg}\right.$, ip) compared to its non-fluorinated analog $\left(\mathrm{ED}_{50}=85.6 \mathrm{mg} / \mathrm{kg}\right)$. To assess the potential mechanism of action, flumazenil test was used and it was proposed that compound $\mathbf{2 6}$ exerts its anticonvulsant activity via benzodiazepine receptors [51]. 
Almasirad et al. have synthesized (2-fluorophenoxyphenyl)-4H-1,2,4-triazoles and determined their anticonvulsant activity by using PTZ-induced lethal convulsion and MES tests in mice. Ethoxytriazole 27 and mercaptotriazole 28 (Fig. 8) showed mild anticonvulsant activity in PTZ and MES tests, respectively. Flumazenil was used for evaluation of benzodiazepine receptors involvement in the anticonvulsant activity of the synthesized compounds. Accordingly, the $\mathrm{ED}_{50}$ value of compound 27 in PTZ test was significantly increased by flumazenil [52].

Various phenoxybenzyl-3-mercapto-1,2,4-triazoles and their alkylthio and ethoxy analogs were synthesized and evaluated as new benzodiazepine-receptor agonists. The biological assessments indicated that compounds with 3-thio or ethoxy substituents have high receptor binding affinity on $\mathrm{GABA}_{\mathrm{A}} / \mathrm{BZD}$ receptor complex and can increase PTZ-induced seizure threshold. Particularly, 5-(4-chloro-2-(2-fluorophenoxy)benzyl)-3-benzylthio-4H-1,2,4triazole (29, Fig. 8) had the highest relative binding affinity $\left(\mathrm{IC}_{50}=0.892 \mathrm{nM}\right)$. It could more significantly increase PTZ-induced seizure threshold comparable to diazepam as the reference drug [53].

Küçükgüzel et al. have reported the synthesis of $3-\{[($ substituted phenyl)methyl $]$ thio $\}-4-$ alkyl/aryl-5-(4-aminophenyl)-4H-1,2,4-triazoles 30 and their Schiff base counterparts 31 (Fig. 8) as anticonvulsant agents. The anticonvulsant evaluation of synthesized compounds by MES, scPTZ revealed that some compounds had anticonvulsant activity at the doses of 100 and $300 \mathrm{mg} / \mathrm{kg}$ in one or both models. Three selected compounds were subjected to oral MES screening in rats at the dose of $30 \mathrm{mg} / \mathrm{kg}$. Among them, $N$-methyltriazole derivative bearing benzylthio moiety (compound 30 with $\mathrm{R}_{1}=\mathrm{Me}, \mathrm{R}_{2}=\mathrm{H}$ ) could protect $50 \%$ of the animals after $1 \mathrm{~h}$ against MES-induced seizures [54].

\section{Triazolones and triazole thiones}

Aryl semicarbazone derivatives 32 (Fig. 9) were found to be promising anticonvulsant agents by blocking the voltage-gated sodium ion channels [55,56]. In the search to find new anticonvulsant agents, 4,5-diphenyl-2H-1,2,4-triazol-3(4H)-one derivatives 33 (Fig. 9) were synthesized via the cyclization reaction of the aryl semicarbazones. The synthesized compounds were tested for their anticonvulsant activity by using four animal model tests including MES, scPTZ, subcutaneous strychnine (scSTY), and subcutaneous picrotoxin 
(scPIC). All the compounds bearing 4-fluorophenyl on the N-4 of triazolone ring showed wide spectrum of anticonvulsant activity. Also, 4-(2,4/2,5-dimethylphenyl) derivatives containing unsubstituted phenyl on the C-3 of triazolone had noticeable anticonvulsant activity at the doses of 100 and $300 \mathrm{mg} / \mathrm{kg}$. The enzymatic GABA assay in brain tissue extracts indicated that the prototype triazolones exhibit anticonvulsant activity via GABAmediation [57].

The synthesis and anticonvulsant evaluation of 1,2,4-triazol-3(2H)-one 34 and its thione analog 35 (Fig. 10) were described by Güniz Küçükgüzel and coworkers. Based on PTZ model test, these compounds with $30-40 \%$ protection had mild anticonvulsant activity at the dose of $100 \mathrm{mg} / \mathrm{kg}$ [58].

Kahveci and coworkers synthesized 5-substituted 1,2,4-triazol-3-one derivatives and tested them by using MES, PTZ and minimal clonic seizure $(6 \mathrm{~Hz})$ models of epilepsy. Among the tested compounds, the 5-methyl analog 36 (Fig. 10) showed promising anticonvulsant activity and was selected for further studies [59].

The effect of 5-(3-chlorophenyl)-4- $p$-tolyl-2H-1,2,4-triazole-3(4H)-thione (37) and its 4-( $p$ bromophenyl) analog 38 (Fig. 10) on protective action of four different classical antiepileptic drugs (carbamazepine, phenobarbital, phenytoin and sodium valproate) was evaluated by using MES method in mice. Based on the results, compound $\mathbf{3 7}$ enhanced the anticonvulsant activity of valproate because of the pharmacokinetic interaction while had no impact on the carbamazepine, phenobarbital and phenytoin activities. Compound $\mathbf{3 8}$ increased the total brain concentrations of carbamazepine (by 68\%) and valproate (by $40 \%$ ) with no effect on total brain concentrations of phenobarbital in mice [60,61]. Plech et al have reported the synthesis and anticonvulsant activity of several 1,2,4-triazole-3-thiones. Based on their results from the MES-induced seizure and neurotoxicity tests, 5-(3-chlorophenyl)-4-(4fluorophenyl)-2H-1,2,4-triazole-3(4H)-thione (39, Fig. 10) with the $\mathrm{ED}_{50}=35.2 \mathrm{mg} / \mathrm{kg}, \mathrm{TD}_{50}$ value of $136.7 \mathrm{mg} / \mathrm{kg}$ and $\mathrm{PI}=3.9$ was the most promising anticonvulsant agent [62]. In another study by the same group, a series of 4-alkyl-1,2,4-triazole-3-thiones were synthesized and screened by MES test. The obtained results demonstrated that the length of the alkyl chain plays an important role in the anticonvulsant activity. Most compounds had better activity than valproate after 15 min via systemic administration. The best results was obtained by 4-butyl-5-(3-chlorophenyl)-2H-1,2,4-triazole-3(4H)-thione (40, Fig. 10) with $\mathrm{ED}_{50}=38.5$ $\mathrm{mg} / \mathrm{kg}$ and $\mathrm{PI}=10.3$. Other derivatives with longer alkyl chains such as 4-decyl and 4- 
dodecyl did not have any significant activity. Chromatographic analysis by using HPLC with diode array detector revealed that the lack of permeability through the blood-brain barrier was the reason for the lack of activity [63].

In the next work on 4-alkyl-1,2,4-triazole-3-thiones, Plech and co-workers replaced the 5-(3chlorophenyl) group by 5-(3-chlorobenzyl/2,3-dichlorophenyl). The synthesized compounds were assessed as anticonvulsant agents by using MES test. The acute adverse effect of the active compounds due to the impairment of motor performance was evaluated in the chimney test. In the 5-(3-chlorobenzyl)- series, compounds bearing ethyl, butyl, pentyl, hexyl, and heptyl side chain on the N-4 showed $100 \%$ protection at the dose of $300 \mathrm{mg} / \mathrm{kg}$ at four pretreatment times (i.e., 15, 30, 60 and $120 \mathrm{~min}$ ). Generally, all active compounds were effective after $120 \mathrm{~min}$, which would be considered as long lasting anticonvulsant agents. Based on the toxicity and the profile of activity, 5-(3-chlorobenzyl)-4-hexyl-2H-1,2,4triazole-3(4H)-thione (41, Fig. 10) was the most promising agent $\left(\mathrm{ED}_{50}=72.1 \mathrm{mg} / \mathrm{kg}\right.$ and PI $>13.9$ after $15 \mathrm{~min}$ ). Radioligand binding assay indicated that these compounds can act via direct or allosteric modulation of $\mathrm{GABA}_{\mathrm{A}}$ receptors [64].

Siddiqui et al. have synthesized some indole-based $2 H$-1,2,4-triazole-3(4H)-thiones (42, Fig. 10) and tested them as anticonvulsant agents by MES model method. Among the tested compounds, analogs containing $\mathrm{R}=2-\mathrm{Cl}, 2-\mathrm{Me}$ or $3-\mathrm{Me}$ substituents showed anticonvulsant activity comparable to phenytoin and carbamazepine. The SAR study indicated that the introduction of 2- $\mathrm{Cl}, 2-\mathrm{Me}$ or 3-Me group on the phenyl ring increase the anticonvulsant activity [65].

A series of phenothiazine-derived $2 H$-1,2,4-triazole-3(4H)-thiones were synthesized and screened by MES, PTZ, picrotoxin and BIC-induced seizure model tests. All the compounds had good anticonvulsant activity (60-70\% inhibition) in both models. Particularly, the 4-(4chlorophenyl)-1H-1,2,4-triazole-5(4H)-thione derivative (43, Fig. 10) had equal activity to phenytoin sodium and less activity respect to lamotrigine at the dose of $30 \mathrm{mg} / \mathrm{kg}$. These compounds exerted their anticonvulsant activity by affecting GABAergic system [66].

Several triazole-3(4H)-thione phenytoin hybrids 44 (Fig. 10) were designed and synthesized via the cyclization reaction of thiosemicarbazide intermediate in $\mathrm{NaOH}$ solution. The anticonvulsant activities of the synthesized compounds were evaluated by MES and scPTZ tests. Among the five tested compounds, four of them ( $\mathrm{R}=\mathrm{Et}, \mathrm{Ph}, 4-\mathrm{MeO}-\mathrm{Ph}, 4-\mathrm{Cl}-\mathrm{Ph})$ showed $40 \%$ protection in the PTZ model after orally administration (100 mg/kg). Moreover, 
the anticonvulsant activity of test compounds administrated orally to mice in the MES screening revealed that compounds containing aromatic ring at the N-4 position of triazole3(4H)-thione displayed higher protection against electrically induced seizures than the ethyl substituted analog $(\mathrm{R}=\mathrm{Et})[67]$.

Some tetrazole derivatives linked to 4-aryl-1,2,4-triazole-3-thiones were synthesized by Rostom et al. The synthesized compounds were evaluated by scPTZ and MES model tests. Among them, compound 45 (Fig. 10) with 33\% protection, had mild anticonvulsant activity at the dose of $100 \mathrm{mg} / \mathrm{kg}$ in both models [68].

A series of 4-aryl-1,2,4-triazole-3-thiones bearing 5-(4-phenylthiazol-2-ylamino)- moiety were designed and synthesized by Siddiqui and Ahsan [69]. The designed compounds contain four structural features essential for anticonvulsant activity: hydrophobic domain (HD), hydrogen bonding domain (HBD), electron donor moiety (EDM), and distal hydrophobic domain (DHD) [70]. The MES and scPTZ anticonvulsant screenings demonstrated that compounds $46\left(\mathrm{R}=\mathrm{Cl}, \mathrm{R}_{1}=4-\mathrm{OCH}_{3}\right)$ and $47\left(\mathrm{R}=\mathrm{Br}\right.$ and $\mathrm{R}_{1}=2-\mathrm{Me}$, Fig. 10) possess the most potent activity. The best results was obtained by compound 47 with $\mathrm{ED}_{50}=13.4 \mathrm{mg} / \mathrm{kg}$ and $\mathrm{PI}=51$ in MES test. Furthermore, the median hypnotic dose $\left(\mathrm{HD}_{50}\right)$ of selected compounds was determined by loss of righting reflex. Also, the median lethal dose $\left(\mathrm{LD}_{50}\right)$ was determined by observing the mortality after 24 h, i.p. injection. These compounds displayed a wide margin of safety with $\mathrm{HD}_{50}$ and $\mathrm{LD}_{50}$ values much higher than those of standard drug phenytoin [69].

Bineshmarvasti and co-workers tested a series of $N-4$ substituted triazolylthiazoles against PTZ-induced seizures in mice. Among the tested compounds, 5-(2,4-dimethyl-5-thiazolyl)-4phenyl- derivative 48 at the doses of 50 and $200 \mathrm{mg} / \mathrm{kg}$ and 5-(2-phenyl-4-methyl-5thiazolyl)-4-ethyl- derivative 49 (Fig. 10) at the doses of 50 and $100 \mathrm{mg} / \mathrm{kg}$ showed $80 \%$ protection. The experiment with flumazenil revealed that the activity of these compounds was not related to the binding to the benzodiazepine receptor complex [71].

\section{Fused-triazoles}

\subsection{Bicyclic fused-triazoles}

\subsubsection{Triazolothiadiazines and triazolothiadiazoles}


Deng et al. have described a series of triazolothiadiazines as anticonvulsant agents. The title compounds were synthesized from 4-amino-4H-1,2,4-triazole-3-thiol and phenacyl halides and evaluated by the MES model test. Among the tested compounds, 6-(4-chlorophenyl)-7H1,2,4-triazolo[3,4-b]1,3,4-thiadiazine (50, Fig. 11) was the most promising one with an $\mathrm{ED}_{50}$ $=40.9 \mathrm{mg} / \mathrm{kg}$ and $\mathrm{PI}=6.5[72]$.

In the next work by Deng et al., a number of triazolothiadiazoles 51 and their 5,6-dihydro derivatives 52 (Fig. 11) were designed and synthesized based on triazolothiadiazine structure $\mathbf{5 0}$ and ring construction strategy. The target compounds were initially evaluated by MES and subsequently by chemical substances-induced seizure methods (PTZ, 3MPA and BICinduced seizure tests). In the first step of screening, most of the compounds were active; while triazolothiadiazole derivatives $\mathbf{5 1}$ were more potent than 5,6-dihydro analogs $\mathbf{5 2}$. Especially, 6-(4-chlorophenyl)- derivative $(51, \mathrm{R}=4-\mathrm{Cl})$ was the most potent compound with $\mathrm{ED}_{50}=23.7 \mathrm{mg} / \mathrm{kg}$ and PI $=10.8$. Furthermore, this compound showed protective activity against all chemical-induced seizures, being broad-spectrum anticonvulsant agent [73].

Husain et al. have reported the synthesis and anticonvulsant activity of 3,6-disubstituted1,2,4-triazolo-[3,4-b]1,3,4-thiadiazoles. The obtained data from MES and neurotoxicity screening revealed that bromophenyl- moiety at position 6 is favorable for activity. In particular, compounds 53 and 54 (Fig. 11) exhibited potent activity comparable to standard drugs phenytoin and carbamazepine and successfully passed the rotarod test without any sign of neurotoxicity [74].

\subsubsection{Triazolopyrimidines}

In a study by Jiang et al. in 2012, a series of triazolo[1,5-a]pyrimidine derivatives were synthesized and evaluated against MES-induced seizure test. Among the tested compounds, 7-(heptyloxy)-5-phenyl[1,2,4]triazolo[1,5-a] pyrimidine (55, Fig. 12) with $\mathrm{ED}_{50}=84.9$ $\mathrm{mg} / \mathrm{kg}$ was more potent than valproate as the reference drug $\left(\mathrm{ED}_{50}=272 \mathrm{mg} / \mathrm{kg}\right)[75]$.

Several triazolopyrimidines were synthesized by the cyclization of pyrimidine hydrazines in acetic anhydride or formic acid. The anticonvulsant activity of the title compounds was evaluated against yohimbine-induced clonic seizures. Compound 56 (Fig. 12) namely 7methyl-5-phenyl-4,5-dihydro-[1,2,4]triazolo[1,5-a]pyrimidine with $\mathrm{ED}_{50}=10 \mathrm{mg} / \mathrm{kg}$ and relative potency of 2.51 compared to carbamazepine was the most active compound [76]. 
In the search to find anticonvulsant agents, some 7-phenyl-6,7-dihydro-[1,2,4]triazolo[1,5a]pyrimidin-5(4H)-ones 57 (Fig. 12) were synthesized by the cyclization of methyl cinnamates with 3-amino-1,2,4-triazole. The compounds were primarily evaluated in the MES and rotarod tests and then the active ones were tested by chemically-induced seizure tests. Generally, $N$-alkyl derivatives $(\mathrm{R}=$ alkyl) were less active than their unsubstituted counterparts $(\mathrm{R}=\mathrm{H})$. Also, $o$-halophenyl compounds had better anticonvulsant activity than other halogenated derivatives. Among the tested compounds, 7-(2-bromophenyl)-6,7dihydro-[1,2,4]triazolo[1,5-a]pyrimidin-5(4H)-one with $\mathrm{ED}_{50}$ value of $19.7 \mathrm{mg} / \mathrm{kg}$ and PI value of 34.8 was the most active compound. Its activity was better than those of phenobarbital and valproate and was comparable with carbamazepine, as the reference drugs. Its safety profile as predicted by protective index was much higher than those of standard drugs. Moreover, the potency of representative compound against seizures induced by PTZ, INH, TSZ, 3MPA, and BIC suggested that this compound displays broad spectrum anticonvulsant activity [77].

A series of triazolopyrimidinones were synthesized as new agonists of benzodiazepine receptors. Based on the SAR of triazolobenzodiazepines such as estazolam, novel compounds were designed. Almost all the compounds had better affinity for benzodiazepine binding site in radioligand receptor binding assay respect to diazepam, as benzodiazepine receptor agonist. Especially, 3-(2-chlorobenzyl)-5-methyl-2-phenyl-[1,2,4]triazolo[1,5-a]pyrimidin$7(3 H)$-one (58, Fig. 12) showed the highest affinity $\left(K_{\mathrm{i}}=0.42 \mathrm{nM}\right.$ and $\left.\mathrm{IC}_{50}=0.68 \mathrm{nM}\right)$. The in vivo experiments indicated that compound $\mathbf{5 8}$ had considerable hypnotic and weak anticonvulsant activities with no impairment on learning and memory [78].

\subsubsection{Triazolopyridazines}

A literature survey revealed that pyridazine and pyridazinone derivatives possess anticonvulsant activity [79-81]. Guan et al. have reported that the incorporation of triazole nucleus to the 2,3-positions of pyridazinone ring in 6-phenoxypyridazin-3(2H)-one (59, Fig. 13) improves anticonvulsant activity from median effective dose of $300 \mathrm{mg} / \mathrm{kg}$ to 109.6 $\mathrm{mg} / \mathrm{kg}$ in MES model test [82].

A series of triazolo[4,3-b]pyridazines with different alkoxyl and aryloxy substituents were synthesized based on the structure of compound $\mathbf{6 0}$. The synthesized compounds were 
evaluated by MES and rotarod tests and subsequently by PTZ, INH, 3MPA and TSZ induced seizure tests. According to the results, almost all the compounds were active at primarily screening at the doses of 30 and $100 \mathrm{mg} / \mathrm{kg}$. Compounds with halogen substituents showed higher anticonvulsant potency in the quantitative anticonvulsant assays. Among the tested compounds, 6-(2,4-dichlorophenoxy)-[1,2,4]triazolo[4,3-b]pyridazine (61, Fig. 14) was the most promising agent $\left(\mathrm{ED}_{50}=17.3 \mathrm{mg} / \mathrm{kg}\right.$ and $\left.\mathrm{PI}=22\right)$. Further pharmacological test revealed that prototype compound 61 had median hypnotic dose of $746.6 \mathrm{mg} / \mathrm{kg}$, possessing much better margin of safety compared to reference drugs carbamazepine and phenobarbital. Based on the chemically-induced seizure tests, this analog might activate GAD or inhibit GABA-T, thereby enhancing GABAergic neurotransmission [82].

Moreau et al. have reported 3-amino-7-(2,6-dichlorobenzyl)-6-methyltriazolo[4,3b]pyridazine (62, Fig. 14) and its derivatives as anticonvulsant agents with good activity in MES model of epilepsy [83]. In the search to find better anticonvulsant agents, amide and carboxylic acid derivatives of triazolopyridazine $\mathbf{6 2}$ were synthesized and evaluated by MES and rotarod tests. Based on the results, amide derivatives had better anticonvulsant activity than carboxylic acid derivatives and 2,4-dichloro substituent was essential for their anticonvulsant activities. Notably, 3-amido-7-(2,6-dichlorobenzyl)-6-methyltriazolo[4,3b]pyridazine (63, Fig. 14) was the most active agent (ED ${ }_{50}$ values of 91.1 and $12.5 \mathrm{mg} / \mathrm{kg}$ in the PTZ and MES tests, respectively). Also this compound blocked strychnine-induced tonic extensor seizure with $\mathrm{ED}_{50}$ value of $62.9 \mathrm{mg} / \mathrm{kg}$ [84].

\subsection{Tricyclic fused-triazoles}

\subsubsection{Triazoloquinolines}

A series of 7-substitued-4,5-dihydro-[1,2,4]triazolo[4,3-a]quinolines were synthesized as anticonvulsant agents in 2005 by Quan et al. Among them, 7-benzyloxyl-4,5-dihydro$[1,2,4]$ triazolo[4,3-a]quinoline (64, Fig. 15) found to be the most active compound in the MES and PTZ model tests $\left(\mathrm{ED}_{50}=17.3\right.$ and $24 \mathrm{mg} / \mathrm{kg}$, respectively) [85]. In the another work, diverse 7-alkyl/aryl substitued-4,5-dihydro-[1,2,4]triazolo-[3,4-a]quinolines were synthesized and evaluated by MES, PTZ and rotarod tests. In general, 7-aryloxy derivatives had better anticonvulsant activity than their alkyl counterparts in preliminary screening. Among the arylmethoxy substituted derivatives, compound 65 (Fig. 15) bearing 7-(4- 
fluorobenzyloxyl)- moiety was the most active derivative. Based on obtained pharmacological data, compound 65 displayed $\mathrm{ED}_{50}$ values of 11.8 and $6.7 \mathrm{mg} / \mathrm{kg}$, in MES and PTZ tests and PI value of $4.6[86]$.

The Quan team also synthesized 4,5-dihydro-[1,2,4]triazolo[4,3- $a]$ quinoline-1(2H)-ones and evaluated them initially by MES and neurotoxicity tests. Compound namely 7-benzyloxyl4,5-dihydro-[1,2,4]thiazolo[4,3-a]quinoline-1(2H)-one (66, Fig. 15) showed the lowest toxicity $\left(\mathrm{TD}_{50}=547.5 \mathrm{mg} / \mathrm{kg}\right)$ and good anti-MES activity $\left(\mathrm{ED}_{50}=12.3 \mathrm{mg} / \mathrm{kg}\right)$. The PI value of this compound was greater than PI of the standard drugs phenytoin, phenobarbital, carbamazepine, and valproate. Compound $\mathbf{6 6}$ showed better safety profile $\left(\mathrm{HD}_{50}=1204\right.$ $\mathrm{mg} / \mathrm{kg}$ and $\mathrm{LD}_{50}>3000 \mathrm{mg} / \mathrm{kg}$ ) compared to the mentioned standard drugs. Moreover, the anticonvulsant activity of triazolo[4,3-a]quinoline-1(2H)-one $\mathbf{6 6}$ was greater than that of parent triazolo[4,3-a]quinoline 64. Besides 7-benzyloxyl- derivative 66, the 7-heptyloxyanalog 67 (Fig. 15) exhibited high anticonvulsant activity in the MES test $\left(\mathrm{ED}_{50}=9.8 \mathrm{mg} / \mathrm{kg}\right)$ [87]. Based on these findings, 7-heptyloxy-[1,2,4]triazolo[4,3-a]quinolin-2-ones with different substituents at $\mathrm{N}-2$ of triazolone ring were synthesized and evaluated. Among the tested compounds, 2-propionyl derivative 68 (Fig. 15) with $\mathrm{ED}_{50}=8.2 \mathrm{mg} / \mathrm{kg}, \mathrm{TD}_{50}=318.3$ $\mathrm{mg} / \mathrm{kg}$, and $\mathrm{PI}=39.0$ was the best compound [88].

Two series of 5-aryl-3,4-dihydro-1,2,4-triazolo[4,3-a]quinolines were also reported as anticonvulsant agents. It was proposed that these types of compounds could have better lipophilic properties and higher permeability to the blood-brain barrier due to the presence of the 5-aryl group. These compounds were evaluated by MES, scPTZ and rotarod neurotoxicity tests. Based on the results, the 1,2,4-triazolo[4,3-a]quinolines had better activity than their triazolone counterparts 69 (Fig. 15). Compounds with electron withdrawing group had better activity. The 5-(3-fluorophenyl)- derivative $\mathbf{7 0}$ (Fig. 15) was the most promising anticonvulsant agent $\left(\mathrm{ED}_{50}=27.4 \mathrm{mg} / \mathrm{kg}\right.$ in the $\mathrm{MES}, \mathrm{ED}_{50}=22.0 \mathrm{mg} / \mathrm{kg}$ in $\mathrm{PTZ}$ test and $\mathrm{PI}=$ 3.33) [89].

According to the SAR studies by Quan et al. [90], it was proposed that the increasing of electron density at the triazole nucleus improves compound binding to the receptor. Several 5-phenyl-[1,2,4]-triazolo[4,3-a]quinoline derivatives with different electron donor and acceptor substituents were synthesized and evaluated by MES and rotarod neurotoxicity test. The obtained results revealed that the length of the alkoxy chain had important effect on anticonvulsant activity. Almost all the tested compounds had anti-MES activities at the dose 
of $30 \mathrm{mg} / \mathrm{kg}$. The in vivo experiments revealed that 7-hexyloxy-5-phenyl-[1,2,4]-triazolo[4,3a] quinoline (71, Fig. 15) had the highest anticonvulsant potency $\left(\mathrm{ED}_{50}=6.5 \mathrm{mg} / \mathrm{kg}\right.$ and $\mathrm{PI}=$ 35.1). Its activity was better than that of the reference drug phenytoin $\left(\mathrm{ED}_{50}=9.5 \mathrm{mg} / \mathrm{kg}\right)$ [90].

Another series of triazolo[4,3-a]quinolines bearing a 5-alkoxy substituent were synthesized and evaluated by Quan et al. in 2009. It assumed that the presence of a 4,5-double bond in the quinoline ring and the conjugation effect with the oxygen atom of 5-alkoxy would increase the electron density on the triazole motif which being favorable for affinity to the receptor. Among the tested compounds, 5-hexyloxy derivative 72 (Fig. 15) found to be the most potent compound $\left(\mathrm{ED}_{50}=19.0 \mathrm{mg} / \mathrm{kg}\right.$ in the MES test and $\left.\mathrm{PI}=5.8\right)$. Based on the chemicallyinduced seizure tests, PTZ, INH, TSZ, 3MPA and strychnine, this compound might act via effect on GABAergic neurotransmission, activation of GAD or inhibition of GABA-T in the brain [91].

\subsubsection{Triazolo- quinazoline, phthalazine and quinoxaline derivatives}

Synthesis and anticonvulsant activity of some substituted 1,2,4-triazoloquinazolines have been described by Zheng et al. in 2013. In the first stage of MES screening at the dose of 100 $\mathrm{mg} / \mathrm{kg}$, triazolo[4,3-c] quinazolin-3-amine derivatives were the most active compounds and other series had any significant activity at the same dose. Then, different 5-phenyl triazolo[4,3-c] quinazolin-3-amines were evaluated by MES and rotarod tests. Generally compounds with electron withdrawing substitutions had better potencies than their electron releasing counterparts. Particularly, 5-(2-bromophenyl)-[1,2,4]triazolo[3,4-c]quinazolin-3amine (73, Fig. 16) with an $\mathrm{ED}_{50}=27.4 \mathrm{mg} / \mathrm{kg}$ and $\mathrm{PI}=5.8$ showed better anticonvulsant activity than valproate [92].

Various triazolophthalazines were synthesized starting from the reaction of 1,4dichlorophthalazine and formic hydrazine in xylene. The title compounds were evaluated by the MES and PTZ induced seizure tests and rotarod assay. The pharmacological results revealed that para-substituted phenyl derivatives had better activities than counterparts with other patterns of substitution. Also, in the alkyl substituted series, the length of the alkyl chain had important effect on their anticonvulsant activity. Although most compounds had good anticonvulsant activity but $p$-chlorophenoxyl derivative $\mathbf{7 4}$, and $n$-heptyloxy analog $\mathbf{7 5}$ 
(Fig. 16) showed the highest anticonvulsant activity $\left(\mathrm{ED}_{50}=7.1,11 \mathrm{mg} / \mathrm{kg}\right.$, and $\mathrm{PI}=5.2$ and 8 , respectively) [93].

Wagle et al. synthesized two series of triazolo[4,3-a]quinoxalines 76 and 77 (Fig. 16) starting from 3-methyl quinoxaline-2-one. The synthesized compounds were evaluated by PTZ-induced seizure test. Some compounds showed $100 \%$ protection at the dose of 10 $\mathrm{mg} / \mathrm{kg}$, comparable to diazepam as the reference drug [94].

\subsubsection{Triazolobenzothiazines}

A number of $4 H$-[1,2,4]triazolo[4,3-d]benzo[b][1,4]thiazines containing 7-alkoxy substituent were synthesized starting from 5-methoxybenzo $[d]$ thiazol-2-amine. The in vivo biological evaluation of target compounds by MES and rotarod tests in mice demonstrated that 7-(2fluorobenzyloxy)- derivative $\mathbf{7 8}$ (Fig. 17) can be considered as the most active compound $\left(\mathrm{ED}_{50}=17.0 \mathrm{mg} / \mathrm{kg}, \mathrm{TD}_{50}=243.9 \mathrm{mg} / \mathrm{kg}\right)$. The neurotoxicity of compound $\mathbf{7 8}$ was significantly lower than that of carbamazepine [95].

\subsubsection{Tricyclic fused-triazoles containing 7-membered ring}

Triazolobenzodiazepine class of compounds is widely used in the treatment of central nervous system disorders. Several triazolobenzodiazepines are marketed as anticonvulsant, sedative, sleep inducer agents [96,97]. In general, benzodiazepines improve the GABA inhibitory effect by binding to the specific site (BZD receptor) and increase the frequency of chloride ion channel $[98,99]$. Estazolam (3), alprazolam (4), and triazolam (6), are examples of well-known triazolobenzodiazepine derivatives (Fig. 3). The annelating benzodiazepine system with an electron-rich azole ring such as triazole can increase the basicity and stability of this system, and also results in active compounds with high affinity to the benzodiazepine receptors. The triazole ring acts as proton-accepting group which putatively interacts with a histidine residue in the $\mathrm{GABA}_{\mathrm{A}}$ receptor complex [100].

Based on the structures of alprazolam (4), and triazolam (6), a series of triazolo[4,3a][1,4]benzodiazepines 79 (Fig. 18) were synthesized starting from 2-(2-chloroacetyl)amino4-chloro-2'-fluorobenzophenone. The synthesized compounds were tested against PTZ and MES-induced seizures. Among the tested compounds, those with 3- or 4-pyridinyl, 4- 
fluorophenyl and 2-bromo-5-methoxyphenyl moiety showed 100\% protection in PTZ model test at the dose of $4 \mathrm{mg} / \mathrm{kg}$, without any protection against MES-induced seizures [101].

In the search to find new anticonvulsant agents, 10-alkoxy-5,6-dihydro-triazolo[4,3d]benzo[f][1,4] oxazepines 80 (Fig. 18) were introduced by Deng et al. in 2010. The in vivo activity of the title compounds was examined by MES and rotarod tests. Most compounds were active at the dose of $100 \mathrm{mg} / \mathrm{kg}$ in the MES screening. In general, alkylated compounds were more active than substituted benzyl derivatives. Also, the size of alkyl chain had important effect on their activities. Among them, 10-heptyloxy-5,6-dihydro-triazolo[4,3d]benzo[f][1,4]oxazepine was the most active compound $\left(\mathrm{ED}_{50}\right.$ value of $6.9 \mathrm{mg} / \mathrm{kg}$ and PI value of 9.5). Further studies of the prototype compound by using different chemicallyinduced seizure tests suggested that this compound exhibited anticonvulsant activity via GABA-modulating mechanisms [102].

In the field of benzazepine agents, 7-butyloxy-1,3,4,5-tetrahydro-2 $\mathrm{H}$-1-benzazepin-2-one showed remarkable activity in the MES test $\left(\mathrm{ED}_{50}=52.8 \mathrm{mg} / \mathrm{kg}\right)$. Accordingly, tricyclic compounds namely 8-alkoxy-5,6-dihydro-4H-[1,2,4]triazolo[4,3-a][1]benzazepin-1-ones 81 (Fig. 18) were designed by the incorporation of triazolone ring to the benzazepine scaffold. Based on the data obtained from anticonvulsant tests, two promising compounds were 8heptyloxy and 8-hexyloxy derivatives $\left(\mathrm{ED}_{50}\right.$ in the MES test $=17.9,17.6 \mathrm{mg} / \mathrm{kg}$, and $\mathrm{PI}=$ 63.4, 62.4, respectively). On the other hand, 8-pentyloxy-5,6-dihydro- $4 H$-[1,2,4]triazolo[4,3a][1]benzazepin-1-one with $\mathrm{ED}_{50}$ value of $38.0 \mathrm{mg} / \mathrm{kg}$ and PI value of 29.1 was the most active compound in the scPTz test. The SAR study revealed that the length of the alkyl chain has a direct impact on the anticonvulsant activity of the 8-alkoxy derivatives. In the alkoxy series, compounds bearing 5-7 carbons on the side chain had better activity. Analyzing the activities of the benzyloxy analogs demonstrated that the introduction of 3-fluoro group on the benzyl moiety led to stronger activity [103].

\section{Miscellaneous triazole derivatives}

In the search for finding 5-aryl-1,2,4-triazole compounds as potential CNS active compounds, a 4-methyl-3-methylsulfonyl- analog 82 showed the capability to block the tonic extensor seizures induced by strychnine. The study by Kehne et al. revealed that the compound $\mathbf{8 2}$ protects mice against strychnine-induced seizures following either intraperitoneal $\left(\mathrm{ED}_{50}=\right.$ 
$12.8 \mathrm{mg} / \mathrm{kg})$ or oral $\left(\mathrm{ED}_{50}=7.3 \mathrm{mg} / \mathrm{kg}\right)$ administration. The $\mathrm{ED}_{50}$ value of compound 82 against PTZ-induced seizure was $55 \mathrm{mg} / \mathrm{kg}$. This compound has the profile of a functional agonist at the strychnine-sensitive glycine receptor in its capacity to antagonize selectively strychnine seizures [104].

A number of 3-(3,4-diaryl-1,2,4-triazol-5-yl)propenoic acids were synthesized by the reaction of $N 3$-substituted amidrazones and maleic anhydride in ethyl ether. Among the synthesized compounds, the anticonvulsant and antinociceptive activities of compound $\mathbf{8 3}$ were evaluated in mice. The results showed that compound $\mathbf{8 3}$ had anticonvulsive activity and potent antinociceptive action. In particular, this compound exhibited a significant anticonvulsant activity in the PTZ-induced seizures and decreased the incidence of tonic seizures and the lethality at the doses of 50 and $100 \mathrm{mg} / \mathrm{kg}$. Also, some behavioral properties of compound $\mathbf{8 3}$ were investigated in mice [105].

\section{Conclusion}

Recently, there has been considerable interest in the development of novel triazole-based anticonvulsant agents. The search for potent triazole anticonvulsants with more selectivity and lower toxicity continues intensively in medicinal chemistry. In our review, we have tried to depict the recent researches which made in the design and development of novel anticonvulsant compounds with triazole nucleus. Structurally, the triazole compounds with noticeable anticonvulsant activity could be mainly categorized as: i) $N$-(arylalkyl)triazoles, ii) $\mathrm{N}$-aryltriazoles, iii) 3,5-disubstituted-4H-1,2,4-triazoles, iv) triazolones and triazole thiones, v) fused-triazoles and vi) poly-substituted triazoles (Fig. 20). Among them, triazole thiones, and fused-triazoles were considered more greatly by medicinal chemist for lead generation in the field of convulsive disorders. The anticonvulsant effects of triazole containing compounds have been studied in different phases. Many of triazole-based compounds showed potent anticonvulsant activities with high selectivity and low toxicity which turn them in to promising lead compounds. The representative lead compounds in each category can prove to be useful for further designing new anticonvulsant agents. 


\section{Acknowledgments}

This work was supported by grants from the Research Council of Tehran University of Medical Sciences, Research Council of Mazandaran University of Medical Sciences, and Iran National Science Foundation (INSF).

\section{References}

[1] R. Ali, M.A. Khan, N. Siddiqui, Past, present and future of antiepileptic drug therapy Finding a place for heterocyclics. Mini Rev. Med. Chem. 15 (2015) 1024-50.

[2] T.W. Strine, R. Kobau, D.P. Chapman, D.J. Thurman, P. Price, L.S. Balluz, Psychological distress, comorbidities, and health behaviors among U.S. adults with seizures: results from the 2002 National Health Interview Survey. Epilepsia, 46 (2005) 1133-1139.

[3] Z. Tolou Ghamari, J. Mehavari Habibabadi, A.A. Palizban, Evidence-based pharmacotherapy of epilepsy. Arch. Neurosci. 2 (2015) e18468. doi: 10.5812/archneurosci.18468.

[4] (a) W. Lasoń, M. Chlebicka, K. Rejdak, Research advances in basic mechanisms of seizures and antiepileptic drug action. Pharmacol. Rep. 65 (2013) 787-801; (b) G. Gatti, I. Bonomi, G. Jannuzzi, E. Perucca, The new antiepileptic drugs: pharmacological and clinical aspects. Curr. Pharm. Des. 6 (2000) 839-860.

[5] WHO Media centre, Fact sheet N999, May 2015, www.who.int/mediacentre/factsheets/fs $999 / \mathrm{en} /$.

[6] L.J. Stephen, M.J. Brodie, Antiepileptic drug monotherapy versus polytherapy: pursuing seizure freedom and tolerability in adults. Curr. Opin. Neurol. 25 (2012) 164-172.

[7] K.S. Walia, E.A. Khan, D.H. Ko, S.S. Raza, Y.N. Khan, Side effects of antiepileptics--a review. Pain Pract. 4 (2004) 194-203.

[8] M. Privitera, Current challenges in the management of epilepsy. Am. J. Manag. Care 17 (2011) Suppl 7: S195-203.

[9] P.N. Patsalos, Drug interactions with the newer antiepileptic drugs (AEDs)--part 1: pharmacokinetic and pharmacodynamic interactions between AEDs. Clin. Pharmacokinet. 52 (2013) 927-966. 
[10] W. Löscher, H. Klitgaard, R.E. Twyman, D. Schmidt, New avenues for anti-epileptic drug discovery and development. Nat. Rev. Drug Discov. 12 (2013) 757-776.

[11] A. Pitkänen, P.A. Schwartzkroin, S.L. Moshé, Models of seizures and epilepsy. Amsterdam: Elsevier; 2006.

[12] M. Bialer, H.S. White, Key factors in the discovery and development of new antiepileptic drugs. Nat. Rev. Drug Discov. 9 (2010) 68-82.

[13] M.R. Sarkisian, Overview of the current animal models for human seizure and epileptic disorders. Epilepsy Behav. 2 (2001) 201-216.

[14] W. Löscher, Critical review of current animal models of seizures and epilepsy used in the discovery and development of new antiepileptic drugs. Seizure 20 (2011) 359-368.

[15] T.L. Gilchrist, Heterocyclic Chemistry, 3rd ed.; Pearson Education India: Singapore, 2005, pp. 298-307.

[16] S. Kubota, M. Uda, 1,2,4-Triazoles. IV. Tautomerism of 3,5-disubstituted 1,2,4-triazoles Chem. Pharm. Bull. 23 (1975) 955-966.

[17] A.V. Dolzhenko, G. Pastorin, A.V. Dolzhenko, W.K. Chui, An aqueous medium synthesis and tautomerism study of 3(5)-amino-1,2,4-triazoles. Tetrahedron Lett. 50 (2009) 2124-2128.

[18] B. Kahveci, F. Y1lmaz, E. Menteşe, F.Ş. Beriş, Effect of microwave irradiation on the synthesis of 1,2,4-triazol-3-one derivatives and their antimicrobial activities. J. Chem. Res. 8 (2012) 484-488.

[19] S.M. Hashemi, H. Badali, H. Irannejad, M. Shokrzadeh, S. Emami, Synthesis and biological evaluation of fluconazole analogs with triazole-modified scaffold as potent antifungal agents, Bioorg. Med. Chem. 23 (2015) 1481-1491.

[20] S. Emami, S. Shojapour, M.A. Faramarzi, N. Samadi, H. Irannejad, Synthesis, in vitro antifungal activity and in silico study of 3-(1,2,4-triazol-1-yl)flavanones. Eur. J. Med. Chem. 66 (2013) 480-488.

[21] S.M. Hashemi, H. Badali, M.A. Faramarzi, N. Samadi, M.H. Afsarian, H. Irannejad, S. Emami, Novel triazole alcohol antifungals derived from fluconazole: Design, synthesis and biological activity. Mol. Divers. 19 (2015) 15-27. 
[22] A. Tahghighi, S. Razmi, M. Mahdavi, P. Foroumadi, S.K. Ardestani, S. Emami, F. Kobarfard, S. Dastmalchi, A. Shafiee, A. Foroumadi, Synthesis and antileishmanial activity of 5-(5-nitrofuran-2-yl)-1,3,4-thiadiazol-2-amines containing $\mathrm{N}$-[(1-benzyl-1H1,2,3-triazol-4-yl)methyl] moieties. Eur. J. Med. Chem. 50 (2012) 124-128.

[23] R. Kharb, M. Shahar Yar, P.C. Sharma, New insights into chemistry and anti-infective potential of triazole scaffold. Curr. Med. Chem. 18 (2011) 3265-3297.

[24] R.S. Keri, S.A. Patil, S. Budagumpi, B.M. Nagaraja, Triazole: a promising antitubercular agent. Chem. Biol. Drug Des. 86 (2015) 410-423.

[25] E.M. Flefel, W.A. Tantawy, W.A. El-Sayed, H.H. Sayed, N.M. Fathy, Synthesis and anticancer activity of new substituted pyrazoles and their derived 1,2,4-triazoles and sugar derivatives. J. Heterocyclic Chem. 2 (2013) 344-350.

[26] R. Kaur, A.R. Dwivedi, B. Kumar, V. Kumar, Recent developments on 1,2,4-triazole nucleus in anticancer compounds: a review. Anticancer Agents Med. Chem. (2015), in press.

[27] S. Pokuri, R.K. Singla, V.G. Bhat, G.G. Shenoy, Insights on the antioxidant potential of 1,2,4-triazoles: synthesis, screening \& QSAR studies. Curr. Drug Metab. 15 (2014) 38997.

[28] H. Akrami, B.F. Mirjalili, M. Khoobi, A. Moradi, H. Nadri, S. Emami, A. Foroumadi, M. Vosooghi, A. Shafiee, 9H-Carbazole derivatives containing the $N$-benzyl-1,2,3triazole moiety as new acetylcholinesterase inhibitors. Arch. Pharm. 348 (2015) 366374.

[29] R. Paprocka, M. Wiese, A. Eljaszewicz, A. Helmin-Basa, A. Gzella, B. ModzelewskaBanachiewicz, J. Michalkiewicz, Synthesis and anti-inflammatory activity of new 1,2,4triazole derivatives. Bioorg. Med. Chem. Lett. 25 (2015) 2664-2667.

[30] J.K. Sahu, S. Ganguly, A. Kaushik, Triazoles: a valuable insight into recent developments and biological activities. Chin. J. Nat. Med. 11 (2013) 456-65.

[31] M. Asif, Review on psychopharmacological activities of substituted triazole analogues. Know. Res. 1 (2014) 68-78.

[32] D.W. Robertson, J.H. Krushinski, E.E. Beedle, J.D. Leander, D.T. Wong, R.C. Rathbun, Structure-activity relationships of (arylalkyl)imidazole anticonvulsants: comparison of 
the (fluorenylalkyl)imidazoles with nafimidone and denzimol. J. Med. Chem. 29 (1986) $1577-1586$.

[33] G. Graziani, F. Tirone, E. Barbadoro, R. Testa, Denzimol, a new anticonvulsant drug. I. General anticonvulsant profile. Arzneimittelforschung. 33 (1983) 1155-1160.

[34] K.A. Walker, M.B. Wallach, D.R. Hirschfeld, 1-(Naphthylalkyl)-1H-imidazole derivatives, a new class of anticonvulsant agents. J. Med. Chem. 24 (1981) 67-74.

[35] D. Nardi, A. Tajana, A. Leonardi, R. Pennini, F. Portioli, M.J. Magistretti, A. Subissi, Synthesis and anticonvulsant activity of $N$-(benzoylalkyl)imidazoles and $N$-( $\omega$-phenyl- $\omega$ -hydroxyalkyl)imidazoles. J. Med. Chem. 24 (1981) 727-731.

[36] D. Ashton, J. Fransen, J. Heeres, G.H. Clincke, P.A. Janssen, In vivo studies on the mechanism of action of the broad spectrum anticonvulsant loreclezole. Epilepsy Res. 11 (1992) 27-36.

[37] G.A.R. Johnston, Medicinal chemistry and molecular pharmacology of GABA(C) receptors. Curr. Top. Med. Chem. 2 (2002) 903-913.

[38] E.R. Korpi, G. Grunder, H. Luddens, Drug interactions at GABA $\mathrm{A}$ receptors. Prog. Neurobiol. 67 (2002) 113-159.

[39] A. Karakurt, M.D. Aytemir, J.P. Stables, M. Qzalp, F.B. Kaynak, S. Ozbey, S. Dalkara, Synthesis of some oxime ether derivatives of 1-(2-naphthyl)-2-triazol-1-yl)ethanone and their anticonvulsant and antimicrobial activities. Arch. Pharm. Chem. Life Sci. 339 (2006) 513-520.

[40] S. Emami, A. Kebriaeezadeh, M.J. Zamani, A. Shafiee, Azolylchromans as a novel scaffold for anticonvulsant activity, Bioorg. Med. Chem. Lett. 16 (2006) 1803-1806.

[41] A. Kebriaeezadeh, S. Emami, M. Ebrahimi, M. Sharifzadeh, R. Khorasani, A. Shafiee, Anticonvulsant and antiepileptogenic effects of azolylchromanones on lithiumpilocarpine induced seizures and pentylenetetrazole-kindling model of epilepsy, Biomed. Pharmacother. 62 (2008) 208-211.

[42] H.J. Lankau, K. Unverferth, C. Grunwald, H. Hartenhauer, K. Heinecke, K. Bernoster, R. Dost, U. Egerland, C. Rundfeldt, New GABA-modulating 1,2,4-oxadiazole derivatives and their anticonvulsant activity. Eur. J. Med. Chem, 42 (2007) 873-879. 
[43] N. Ahangar, A. Ayati, E. Alipour, A. Pashapour, A. Foroumadi, S. Emami, 1-[(2Arylthiazol-4-yl)methyl]azoles as a new class of anticonvulsants: design, synthesis, in vivo screening, and in silico drug-like properties. Chem. Biol. Drug Des. 78 (2011) 844852.

[44] J. Chen, X.Y. Sun, K.Y. Chai, J.S. Lee, M.S. Song, Z.S. Quan, Synthesis and anticonvulsant evaluation of 4-(4-alkoxylphenyl ethyl-4H-1,2,4-triazoles as open-chain analogues of alkoxyl-4,5-dihydro[1,2,4]triazolo[4,3-a]quinolones. Bioorg. Med. Chem. 15 (2007) 6775-6781.

[45] Y.Q. Fang, C.L. Sun, D.C. Liua, S.B. Wang, Z.S. Quan, Synthesis and anticonvulsant activity evaluation of 3-alkoxy-4-(4-(hexyloxy/heptyloxy)phenyl)-4H-1,2,4-triazole. Iran. J. Pharm. Res. 14 (2015), 77-87.

[46] S. Kumar, S. Bawa, H. Gupta, Biological activities of quinoline derivatives. Mini Rev. Med. Chem. 9 (2009) 1648-1654.

[47] Y. Oshiro, Y. Sakurai, S. Sato, N. Kurahashi, T. Tanaka, T. Kikuchi, K. Tottori, Y. Uwahodo, T. Miwa, T. Nishi, 3,4-Dihydro-2(1H)-quinolinone as a novel antidepressant drug: synthesis and pharmacology of 1-[3-[4-(3-chlorophenyl)-1-piperazinyl]propyl]-3,4dihydro-5-methoxy-2(1H)-quinolinone and its derivatives. J. Med. Chem. 43 (2000) 177-189.

[48] X.Q. Deng, M.X. Song, Y. Zheng, Z.S. Quan, Design, synthesis and evaluation of the antidepressant and anticonvulsant activities of triazole-containing quinolinones. Eur. J. Med. Chem. 73 (2014) 217-224.

[49] S.B. Wang, P. Jin, F.N. Li, Z.S. Quan, Synthesis and anticonvulsant activity of novel purine derivatives. Eur. J. Med. Chem. 84 (2014) 574-583.

[50] T. Akbarzadeh, S.A. Tabatabai, M.J. Khoshnoud, B. Shafaghi, A. Shafiee, Design and synthesis of 4H-3-(2-phenoxy)phenyl-1,2,4-triazole derivatives as benzodiazepine receptor agonists. Bioorg. Med. Chem. 11 (2003) 769-773.

[51] M. Mahdavi, T. Akbarzadeh, V. Sheibani, M. Abbasi, L. Firoozpour, S.A. Tabatabai, A. Shafiee, A. Foroumadi, Synthesis of two novel 3-amino-5-[4-chloro-2-phenoxyphenyl]4H-1,2,4-triazoles with anticonvulsant activity. Iran. J. Pharm. Res. 9 (2010) 265-269.

[52] A. Almasirad, S.A. Tabatabai, M. Faizi, A. Kebriaeezadeh, N. Mehrabi, A. Dalvandi, A. Shafiee, Synthesis and anticonvulsant activity of new 2-substituted-5-[2-(2- 
fluorophenoxy)phenyl]-1,3,4-oxadiazoles and 1,2,4-triazoles. Bioorg. Med. Chem. Lett. 14 (2004) 6057-6059.

[53] S. Mashayekh, N. Rahmanipour, B. Mahmoodi, F. Ahmadi, D. Motaharian, S. Shahhosseini, H. Shafaroodi, H.R. Banafshe, A. Shafiee, L. Navidpour, Synthesis, receptor affinity and effect on pentylenetetrazole-induced seizure threshold of novel benzodiazepine analogues: 3-Substituted phenoxybenzyl)-4H-1,2,4-triazoles and 2amino-5 phenoxybenzyl)-1,3,4-oxadiazoles. Bioorg. Med. Chem. 22 (2014) 1929-1937.

[54] L. Küçükgüzel, S.G. Küçükgüzel, S. Rollas, G. Ötük-Sanıs, O. Özdemir, I. Bayrak, T. Altug, J.P. Stables, 3-(Arylalkylthio)-4-alkyl/aryl-5-(4-aminophenyl)-4H-1,2,4-triazole derivatives and their anticonvulsant activity. IL Farmaco 59 (2004) 893-901.

[55] J.R. Dimmock, S.C. Vashishta, J.P. Stables. Anticonvulsant properties of various acetylhydrazones, oxamoylhydrazones and semicarbazones derived from aromatic and unsaturated carbonyl compounds. Eur. J. Med. Chem. 35 (2000) 241-249.

[56] J.R. Dimmock, S.C. Vashishtha, J.P. Stables. Ureylene anticonvulsants and related compounds. Pharmazie 55 (2000) 490-494.

[57] M. Shalini, P. Yogeeswari, D. Sriram, J.P. Stables, Cyclization of the semicarbazone template of aryl semicarbazones: synthesis and anticonvulsant activity of 4,5-diphenyl2H-1,2,4-triazol-3(4H)-one. Biomed. Pharmacother. 63 (2009) 187-193.

[58] S. Güniz Küçükgüzel, S. Rollas, H. Erdeniz, M. Kiraz, A. Cevdet Ekinci, A. Vidin, Synthesis, characterization and pharmacological properties of some 4-arylhydrazono-2pyrazoline-5-one derivatives obtained from heterocyclic amines. Eur. J. Med. Chem. 35 (2000) 761-771.

[59] B. Kahveci, E. Menteşe, E. Akkaya, F. Yılmaz, İ.S. Dogan, A. Özel, Synthesis of some novel 1,2,4-triazol-3-one derivatives bearing the salicyl moiety and their anticonvulsant activities. Arch. Pharm. Chem. Life Sci. 347 (2014) 449-455.

[60] J.J. Luszczki, T. Plech, M. Wujec, Influence of 5-(3-chlorophenyl)-4-(4-methylphenyl)2,4-dihydro-3H-1,2,4-triazole-3-thione on the anticonvulsant action of 4 classical antiepileptic drugs in the mouse maximal electroshock-induced seizure model. Pharmacol. Rep. 64 (2012) 970-978.

[61] J.J. Luszczki, T. Plech, M. Wujec, Effect of 4-(4-bromophenyl)-5-(3-chlorophenyl)-2,4dihydro-3H-1,2,4-triazole-3-thione on the anticonvulsant action of different classical 
antiepileptic drugs in the mouse maximal electroshock-induced seizure model. Eur. J. Pharmacol. 690 (2012) 99-106.

[62] T. Plech, B. Kaproń, J.J. Łuszczki, M. Wujec, A. Paneth, A. Siwek, M. Kołaczkowski, M. Żołnierek, G. Nowak, Studies on the anticonvulsant activity and influence on GABAergic neurotransmission of 1,2,4-triazole-3-thione-based compounds. Molecules 19 (2014) 11279-11299.

[63] T. Plech, J.J. Luszczki, M. Wujec, J. Flieger, M. Pizo, Synthesis, characterization and preliminary anticonvulsant evaluation of some 4-alkyl-1,2,4-triazoles. Eur. J. Med. Chem. 60 (2013) 208-215.

[64] T. Plech, B. Kapron, J.J. Łuszczki, A. Paneth, A. Siwek, M. Kołaczkowski, M. Zołnierek, G. Nowak, Studies on the anticonvulsant activity of 4-alkyl-1,2,4-triazole-3 thiones and their effect on GABAergic system. Eur. J. Med. Chem. 86 (2014) 690-699.

[65] N. Siddiqui, M.S. Alam, W. Ahsan, Synthesis, anticonvulsant and toxicity evaluation of 2-(1H-indol-3-yl)acetyl- $N$-(substituted phenyl)hydrazine carbothioamides and their related heterocyclic derivatives. Acta Pharm. 58 (2008) 445-554.

[66] H. Kaur, S. Kumar, S. Lata, K.K. Saxena, A. Kumar, Synthesis of some new triazolyl/oxadiazoly1/thiadiazolylphenothiazines as anticonvulsant agents. Eur. J. Med. Chem. 45 (2010), 3080-3086.

[67] S. Botros, N.A. Khalil, B.H. Naguib, Y. El-Dash, Synthesis and anticonvulsant activity of new phenytoin derivatives. Eur. J. Med. Chem. 60 (2013) 57-63.

[68] S.A. Rostom, H.M. Ashour, H.A. El Razik, F. El Fattah Ael, N.N. El-Din, Azole antimicrobial pharmacophore-based tetrazoles: Synthesis and biological evaluation as potential antimicrobial and anticonvulsant agents. Bioorg. Med. Chem. 17 (2009) 24102422.

[69] N. Siddiqui, W. Ahsan, Triazole incorporated thiazoles as a new class of anticonvulsants: Design, synthesis and in vivo screening. Eur. J. Med. Chem. 45 (2010) $1536-1543$.

[70] S.N. Pandeya, P. Yogeeswari, J.P. Stables, Synthesis and anticonvulsant activity of 4bromophenyl substituted aryl semicarbazones. Eur. J. Med. Chem. 35 (2000) 879-886.

[71] M. Bineshmarvasti, M. Sharifzadeh, A.R. Jalilian, K. Soltaninejad, A. Shafiee, Synthesis and anticonvulsant activity of $\mathrm{N}_{4}$-substituted triazolythiazoles. Daru 11 (2003) 74-78. 
[72] X.Q. Deng, M.X. Song, C.X. Wei, F.N. Li, Z.S. Quan, Synthesis and anticonvulsant activity of 7-alkoxy-triazolo-[3,4-b]benzo[d]thiazoles. Med. Chem. 6 (2010) 313-320.

[73] X.Q. Deng, Z.Q. Dong, M.X. Song, B. Shu, S.B. Wang, Z.S. Quan, Synthesis and anticonvulsant activities of some triazolothiadiazole derivatives. Arch. Pharm. Chem. Life Sci. 345 (2012) 565-573.

[74] Husain, M.A. Naseer, M. Sarafroz, Synthesis and anticonvulsant activity of some novel fused heterocyclic 1,2,4-triazolo-[3,4-b]-1,3,4-thiadiazole derivatives. Acta Pol. Pharm. 66 (2009) 135-140.

[75] N. Jiang, X.Q. Deng, F.N. Li, Z.S. Quan, Synthesis of novel 7-substituted-5-phenyl$[1,2,4]$ triazolo[1,5-a] pyrimidines with anticonvulsant activity. Iran. J. Pharm. Res. 11 (2012) 799-806.

[76] S.A. Said, A.E-G.E. Amr, N.M. Sabry, M.M. Abdalla, Analgesic, anticonvulsant and anti-inflammatory activities of some synthesized benzodiazipine, triazolopyrimidine and bis-imide derivatives. Eur. J. Med. Chem. 44 (2009) 4787-4792.

[77] X.Q. Deng, L.N. Quan, M.X. Song, C.X. Wei, Z.S. Quan, Synthesis and anticonvulsant activity of 7-phenyl-6,7-dihydro-[1,2,4 triazolo[1,5-a]pyrimidin-5(4H)-ones and their derivatives. Eur. J. Med. Chem. 46 (2011) 2955-2963.

[78] M. Faizi, S. Dabirian, H. Tajali, F. Ahmadi, E.R. Zavareh, S. Shahhosseini, S.A. Tabatabai, Novel agonists of benzodiazepine receptors: design, synthesis, binding assay and pharmacological evaluation of 1,2,4-triazolo[1,5-a]pyrimidinone and 3-amino-1,2,4triazole derivatives. Bioorg. Med. Chem. 23 (2015) 480-487.

[79] R. Sivakumar, N. Anbalagan, V. Gunasekaran, J.T. Leonard, Synthesis and anticonvulsant activity of novel 1-substituted-1,2-dihydro-pyridazine-3,6-diones. Biol. Pharm. Bull. 26 (2003) 1407-1411.

[80] P. Xu, S.Y. Wang, Y. Chen, W.Q. Liu, C. Tao, Studies on synthesis, anticonvulsant activity and the structure-activity relationships of 6-(substituted phenyl)-3 (2H) pyridazinones. Yao Xue Xue Bao 26 (1991) 656-660 (Article in Chinese).

[81] A. Perio, J.P. Chambon, R. Calassi, M. Heaulme, K. Biziere, Evaluation of two anticonvulsant amino-pyridazine derivatives in the conflict test in rats. J. Pharmacol. Exp. Ther. 239 (1986):542-547. 
[82] L.P. Guan, X. Sui, X.Q. Deng, Y.C. Quan, Z.S. Quan, Synthesis and anticonvulsant activity of a new alkoxy-[1,2,4]triazolo[4,3-b]pyridazine. Eur. J. Med. Chem. 45 (2010) $1746-1752$.

[83] S. Moreau, P. Coudert, C. Rubat, D. Gardette, D. Vallee-Goyet, J. Couquelet, P. Bastide, P. Tronche, Synthesis and anticonvulsant properties of new benzylpyridazine derivatives. J. Med. Chem. 37 (1994) 2153-2160.

[84] S. Moreau, P. Coudert, C. Rubat, D. Vallee-Goyet, D. Gardette, J.C. Gramainc, J. Couquelet, Synthesis and anticonvulsant properties of triazolo- and imidazopyridazinyl carboxamides and carboxylic acids. Bioorg. Med. Chem. 6 (1998) 983-991.

[85] L.J. Cui, Z.F. Xie, H.R. Piao, G. Li, K.Y. Chai, Z.S. Quan, Synthesis and anticonvulsant activity of 1-substituted-7-benzyloxy-4,5-dihydro-[1,2,4]triazolo[4,3-a]quinoline. Biol. Pharm. Bull. 28 (2005) 1216-1220.

[86] Z.F. Xie, K.Y. Chai, H.R. Piao, K.C. Kwak, Z.S. Quan, Synthesis and anticonvulsant activity of 7-alkoxyl-4,5-dihydro-[1,2,4]triazolo[4,3-a]quinolines. Bioorg. Med. Chem. Lett. 15 (2005) 4803-4805.

[87] H.G. Jin, X.Y. Sun, K.Y. Chai, H.R. Piao, Z.S. Quan, Anticonvulsant and toxicity evaluation of some 7-alkoxy-4,5-dihydro-[1,2,4]triazolo[4,3-a]quinoline-1(2H)-ones. Bioorg. Med. Chem. 14 (2006) 6868-6873.

[88] C.X. Wei, F.N. Li, L.X. Zhao, L.M. Zhao, Z.S. Quan, Synthesis of 2-substituted-7heptyloxy-4,5-dihydro-[1,2,4]triazolo[4,3-a]quinolin-1(2H)-ones with anticonvulsant activity. Arch. Pharm. Chem. Life Sci. 340 (2007) 491-495.

[89] L.P. Guan, Q.H. Jin, G.R. Tian, K.Y. Chai, Z.S. Quan. Synthesis of some quinoline2(1H)-one and 1,2,4-triazolo [4,3-a] quinoline derivatives as potent anticonvulsants. J. Pharm. Pharmaceut. Sci. 10 (2007) 254-262.

[90] L.P. Guan, Q.H. Jin, S.F. Wang, F.N. Li, Z.S. Quan, Synthesis and anticonvulsant activity of 5-phenyl-[1,2,4]-triazolo[4,3-a]quinolines. Arch. Pharm. Chem. Life Sci. 341 (2008) 774-779.

[91] L.J. Guo, C.X. Wei, J.H. Jia, L.M. Zhao, Z.S. Quan, Design and synthesis of 5-alkoxy$[1,2,4]$ triazolo[4,3-a]quinoline derivatives with anticonvulsant activity. Eur. J. Med. Chem. 44 (2009) 954-958. 
[92] Y. Zheng, M. Bian, X.Q. Deng, S.B. Wang, Z.S. Quan, Synthesis and anticonvulsant activity evaluation of 5-phenyl-[1,2,4]triazolo[4,3-c] quinazolin-3-amines. Arch. Pharm. Chem. Life Sci. 346 (2013) 119-126.

[93] L. Zhang, L.P. Guan, X.Y. Sun, C.X. Wei, K.Y. Chai, Z.S. Quan, Synthesis and anticonvulsant activity of alkoxy-[1,2,4]triazolo[3,4-a]phthalazines. Chem. Biol. Drug. Des. 73 (2009) 313-319.

[94] S. Wagle, A.V. Adhikari, N.S. Kumari, Synthesis of some new 4-styryltetrazolo[1,5a]quinoxaline and substituted-4-styryl[1,2,4]triazolo[4,3-a]quinoxaline derivatives as potent anticonvulsants. Eur. J. Med. Chem. 44 (2009) 1135-1143.

[95] L.Q. Zhang, L.P. Guan, C.X. Wei, X.Q. Deng, Z.S. Quan, Synthesis and anticonvulsant activity of some 7-alkoxy-2H-1,4-benzothiazin-3(4H)-ones and 7-alkoxy-4H$[1,2,4]$ triazolo[4,3-d]benzo[b][1,4]thiazines. Chem. Pharm. Bull. 58 (2010) 326-331.

[96] W. Sneader, Comprehensive Medicinal Chemistry, Vol. 1, C. Hansch, P.G. Sammnes, J.B. Taylor, Eds. Pergamon, London, 65 (1990).

[97] G. Moroz, High-potency benzodiazepines: recent clinical results. J. Clin. Psychiatry 65 (2004) 13-18.

[98] R.L. Macdonald, R.W. Olsen, GABA A receptor channels. Annu. Rev. Neurosci. 17 (1994) 569-602.

[99] W. Sieghart, Structure and pharmacology of gamma-aminobutyric acidA receptor subtypes. Pharmacol. Rev. 47 (1995) 181-234.

[100] T.L. Lemke, D.A. Williams. Foye's Principles of Medicinal Chemistry. Lippincott Williams \& Wilkins (2012).

[101] B. Narayana, K.K. Vijaya Raj, B.V. Ashalatha, N.S. Kumari, Synthesis of some new substituted triazolo [4,3-a] benzodiazepine derivatives as potent anticonvulsants. Eur. J. Med. Chem. 41 (2006) 417-422.

[102] X.Q. Deng, C.X. Wei, F.N. Li, Z.G. Sun, Z.S. Quan, Design and synthesis of 10alkoxy-5,6-dihydro-triazolo[4,3- $d]$ benzo[f][1,4]oxazepine derivatives with anticonvulsant activity. Eur. J. Med. Chem. 45 (2010) 3080-3086. 
[103] F.Y. Piao, R.B. Han, W. Zhang, W.B. Zhang, R.S. Jiang, Synthesis and anticonvulsant activity of 8 -alkoxy-5,6-dihydro-4H-[1,2,4]triazolo-4,3,a][1]benzazepin-1-one derivative. Eur. J. Med. Chem. 46 (2011) 1050-1055.

[104] J.H. Kehne, J.M. Kane, F.P. Miller, H.J. Ketteler, D.L. Braun, Y. Senyah, S.F. Chaney, A. Abdallah, M.W. Dudley, A.M. Ogden, et al. MDL 27,531 selectively reverses strychnine-induced seizures in mice. Br. J. Pharmacol. 106 (1992) 910-916.

[105] B. Modzelewska-Banachiewicz, J. Banachiewicz, A. Chodkowska, E. JagiełłoWójtowicz, L. Mazur, Synthesis and biological activity of new derivatives of 3-(3,4diaryl-1,2,4-triazole-5-yl)propenoic acid. Eur. J. Med. Chem. 39 (2004) 873-877. 


\section{Captions:}

Figure 1. Tautomeric forms of triazole

Figure 2. Tautomerism in substituted 1,2,4-triazoles

Figure 3. Well-known CNS active drugs containing triazole nucleus

Figure 4. (Arylalkyl)azoles with anticonvulsant activity

Figure 5. Triazol-1-ylchromanones 14 and triazol-4-ylchromanones $\mathbf{1 5}$ as conformationally constrained analogs of (arylalkyl)azoles

Figure 6. 1,2,4-Oxadiazole- and thiazole-incorporated (arylalkyl)azoles

Figure 7. $N$-Aryltriazoles 20-24

Figure 8. 3,5-Disubstituted-4H-1,2,4-triazoles

Figure 9. Design of 4,5-diphenyl-2H-1,2,4-triazol-3(4H)-ones $\mathbf{3 3}$ from aryl semicarbazones 32

Figure 10. Structures of triazolones and triazole thiones with anticonvulsant activity

Figure 11. Triazolothiadiazine and triazolothiadiazole derivatives

Figure 12. Triazolopyrimidines

Figure 13. Design of triazolopyridazine 60

Figure 14. Triazolopyridazines

Figure 15. Triazoloquinoline derivatives

Figure 16. Triazolo- quinazoline, phthalazine and quinoxaline derivatives

Figure 17. Compound 78, an example of triazolobenzothiazine derivatives

Figure 18. Tricyclic fused-triazoles containing 7-membered ring

Figure 19. Structures of poly-substituted triazoles $\mathbf{8 2}$ and $\mathbf{8 3}$

Figure 20. Pharmacophoric presentation of triazole-based anticonvulsant agents 
$\sum_{\mathrm{H}^{-}}^{\mathrm{N}} \rightleftharpoons{ }_{\mathrm{N}^{-}}^{\mathrm{N}}$

Figure 1. 


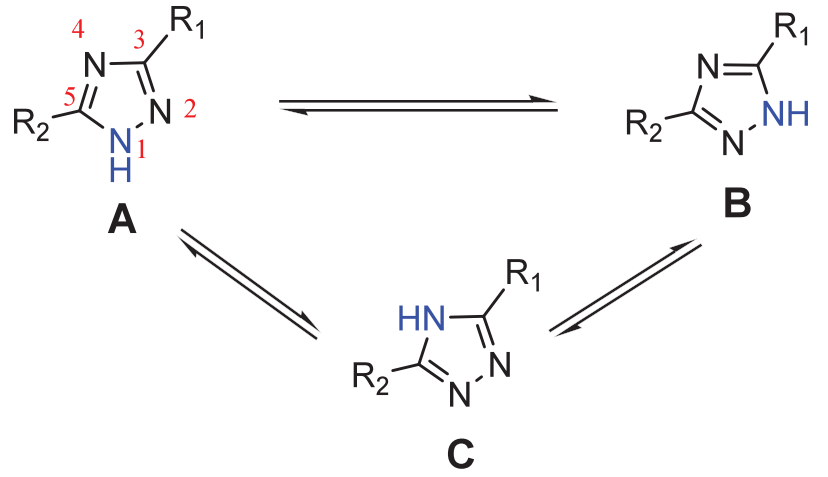

Figure 2. 
<smiles>Cl/C(=C\n1cncn1)c1ccc(Cl)cc1Cl</smiles>

Loreclezole (1)<smiles>CN(C)CCc1c[nH]c2ccc(Cn3cncn3)cc12</smiles>

Rizatriptane (2)<smiles>Clc1ccc2c(c1)C(c1ccccc1)=NCc1nncn1-2</smiles>

Estazolam (3)<smiles>Cc1nnc2n1-c1ccc(Cl)cc1C(c1ccccc1)=NC2</smiles>

Alprazolam (4)<smiles>CCc1cc2c(s1)-n1c(C)nnc1CN=C2c1ccccc1Cl</smiles>

Etizolam (5)<smiles>Cc1nnc2n1-c1ccc(Cl)cc1C(c1ccccc1Cl)=NC2</smiles>

Triazolam (6)<smiles>CN(C)C(=O)c1nc(CNC(=O)CN)n(-c2ccc(Cl)cc2C(=O)c2ccccc2Cl)n1</smiles>

Rilmazafone (7)<smiles>CCc1nn(CCCN2CCN(c3cccc(Cl)c3)CC2)c(=O)n1CCOc1ccccc1</smiles><smiles>CCOC(Cl)(OCC)C(F)(F)F</smiles>

Figure 3. 


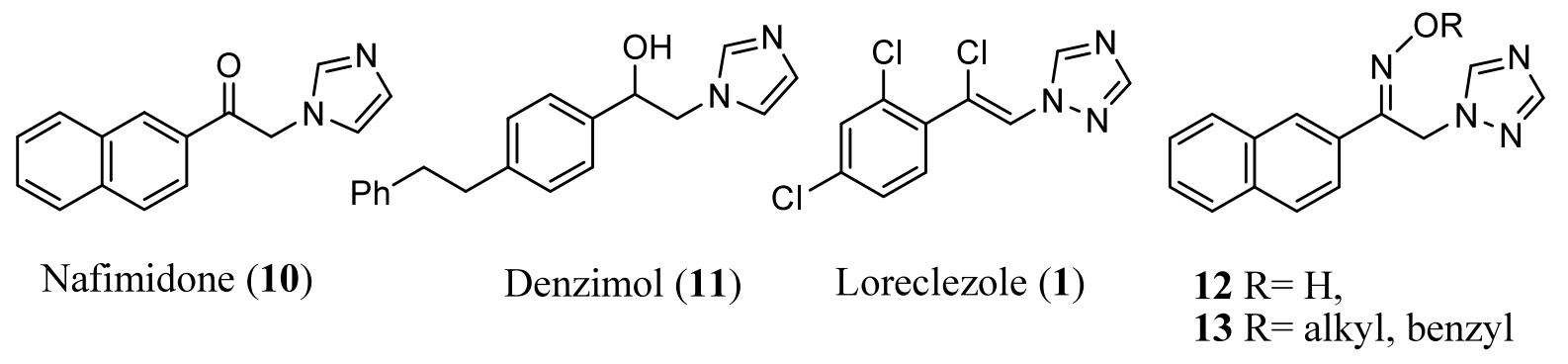

Figure 4. 
<smiles></smiles>

14<smiles></smiles>

15

$$
\begin{aligned}
& \mathrm{X}=\mathrm{O}, \mathrm{NOH} \\
& \mathrm{R}=\mathrm{H}, \mathrm{Cl} \\
& \mathrm{R}_{1}=\mathrm{H}, \mathrm{CH}_{3}
\end{aligned}
$$

Figure 5. 

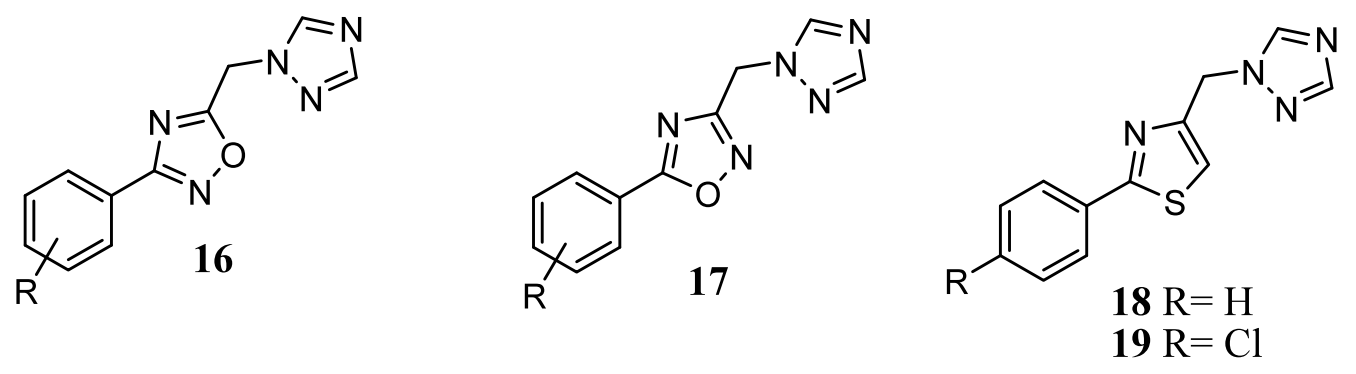

Figure 6. 
<smiles>[R]Oc1ccc(-n2cnnc2CC)cc1</smiles>

$20 \mathrm{R}=n-\mathrm{C}_{7} \mathrm{H}_{15}$

$21 \mathrm{R}=n-\mathrm{C}_{8} \mathrm{H}_{17}$<smiles>[R20]Oc1ccc(-n2cnnc2O[R20])cc1</smiles>

22<smiles>[R]N1C(=O)CCc2cc(-n3cnnc3)ccc21</smiles>

23

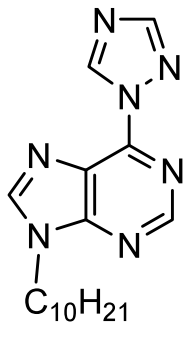

24

Figure 7. 
<smiles>Nc1nnc(-c2ccc(Cl)cc2Oc2ccccc2Cl)[nH]1</smiles>

25

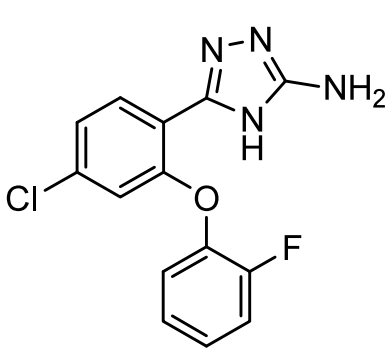

26<smiles>CCOc1nnc(-c2ccccc2Oc2ccccc2F)[nH]1</smiles>

27<smiles>Fc1ccccc1Oc1ccccc1-c1nnc(S)[nH]1</smiles>

28<smiles>[R2]c1cccc(CSc2nnc(-c3ccc(N)cc3)n2[R7])c1</smiles>

Figure 8. 


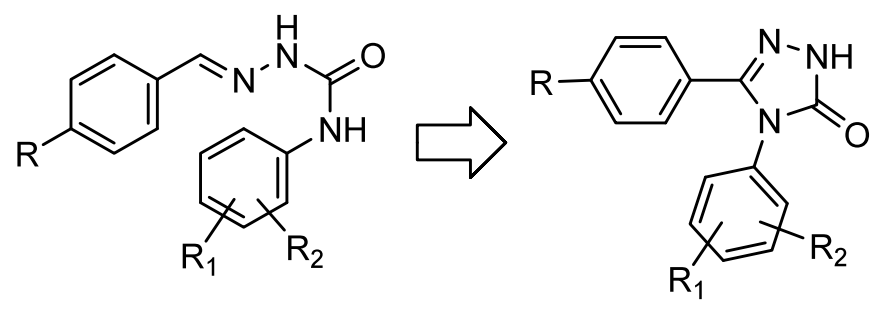

32

33

Figure 9. 


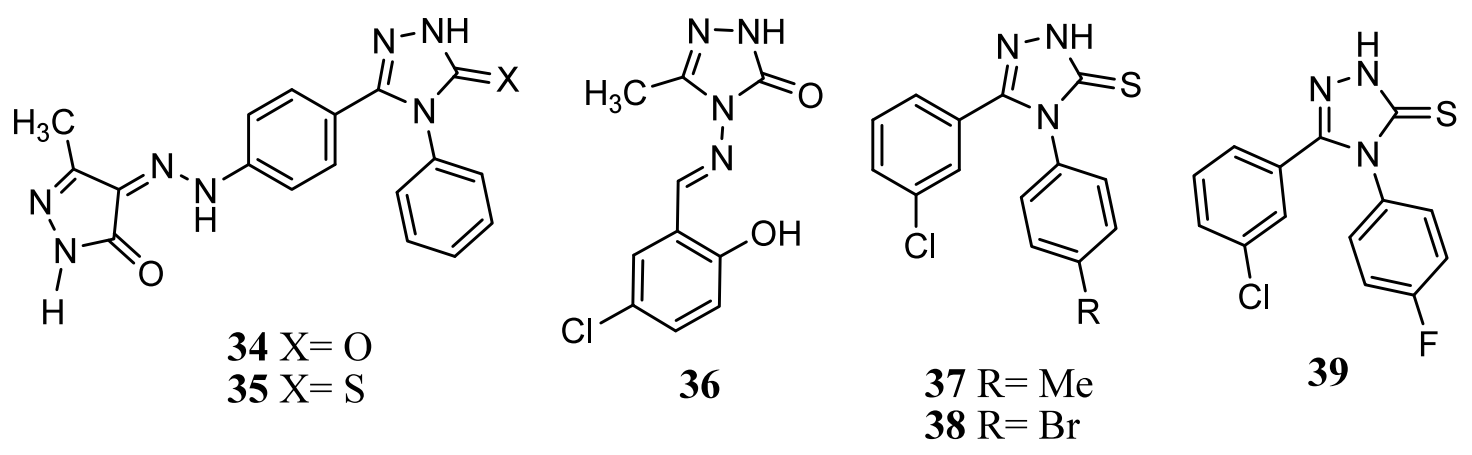<smiles>CCCCn1c(-c2cccc(Cl)c2)n[nH]c1=S</smiles>

40<smiles>[R]c1ccc(-n2c(Cc3c[nH]c4ccccc34)n[nH]c2=S)cc1</smiles>

41<smiles>S=c1[nH]nc(CN2c3ccccc3Sc3ccccc32)n1-c1ccc(Cl)cc1</smiles><smiles>[R]n1c(CN2C(=O)NC(c3ccccc3)(c3ccccc3)C2=O)n[nH]c1=S</smiles>

44<smiles>S=c1[nH]nc(COC(Cn2nnc(-c3ccccc3)n2)c2ccc(Cl)cc2)n1-c1ccccc1</smiles><smiles>[R]c1ccc(-c2csc(Nc3n[nH]c(=S)n3-c3ccccc3)n2)cc1</smiles>

$46 \mathrm{R}=\mathrm{Cl}, \mathrm{R}_{1}=4-\mathrm{OMe}$ $47 \mathrm{R}=\mathrm{Br}, \mathrm{R}_{1}=2-\mathrm{Me}$<smiles>Cc1nc(C)c(-c2n[nH]c(=S)n2-c2ccccc2)s1</smiles>

48<smiles>CCn1c(-c2sc(-c3ccccc3)nc2C)n[nH]c1=S</smiles>

49

Figure 10. 
<smiles>Clc1ccc(C2=Nn3cnnc3SC2)cc1</smiles>

50

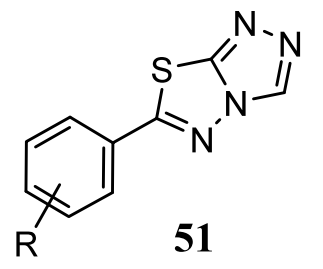

51<smiles>[R]c1ccc(C2Nn3cnnc3S2)cc1</smiles>

52<smiles></smiles>

Figure 11. 


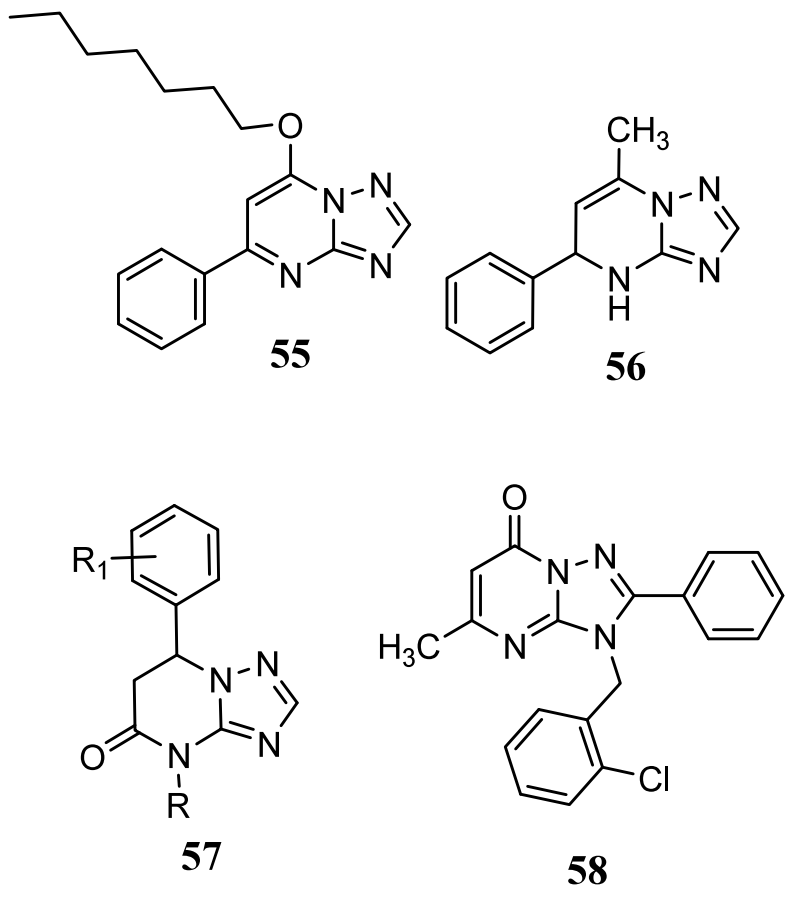

Figure 12. 
<smiles>O=c1ccc(Oc2ccccc2)n[nH]1</smiles>

Figure 13. 

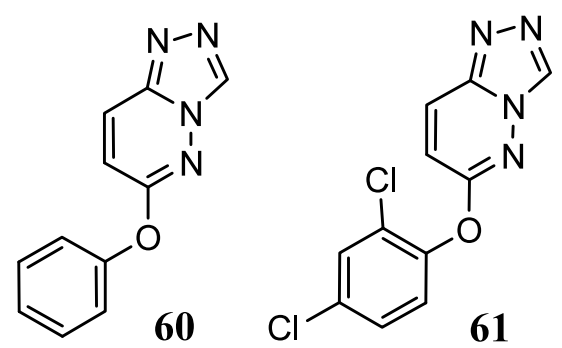

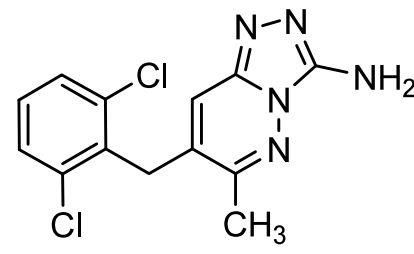

62<smiles>Cc1nn2c(C(N)=O)nnc2cc1Cc1c(Cl)cccc1Cl</smiles>

63

Figure 14. 
<smiles>c1ccc(COc2ccc3c(c2)CCc2nncn2-3)cc1</smiles><smiles>CCOc1ccc2c(c1)CCc1n[nH]c(=O)n1-2</smiles>

67<smiles>O=c1[nH]nc2n1-c1ccc(OCc3ccccc3)cc1CC2</smiles>

65<smiles>CCOc1ccc2c(c1)CCc1nn(C(=O)CC)c(=O)n1-2</smiles><smiles>[R][R]1ccccc1C1Cc2n[nH]c(=O)n2-c2ccccc21</smiles>

69<smiles>Fc1cccc(C2Cc3nncn3-c3ccccc32)c1</smiles>

70<smiles>CCCOc1ccc2c(c1)c(-c1ccccc1)cc1nncn12</smiles>

71<smiles>CCCCCOc1cc2nncn2c2ccccc12</smiles>

72

Figure 15. 
<smiles>Nc1nnc2c3ccccc3nc(-c3ccccc3Br)n12</smiles>

73<smiles>[R]c1nnc2c(C)nc3ccccc3n12</smiles>

76<smiles>[R]Oc1nn2cnnc2c2ccccc12</smiles>

$74 \mathrm{R}=p-\mathrm{ClC}_{6} \mathrm{H}_{5}$

$75 \mathrm{R}=n$-heptyl

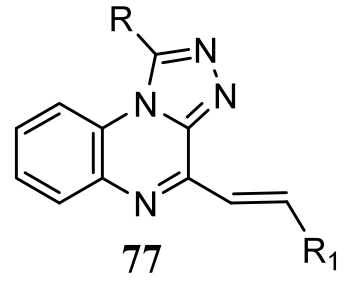

Figure 16. 


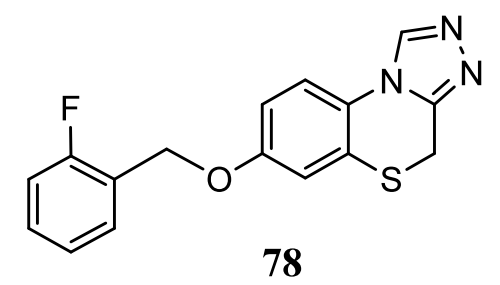

Figure 17. 


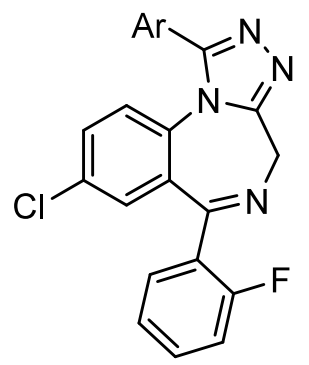

79<smiles>[R6]Oc1ccc2c(c1)-c1nncn1CCO2</smiles>

80

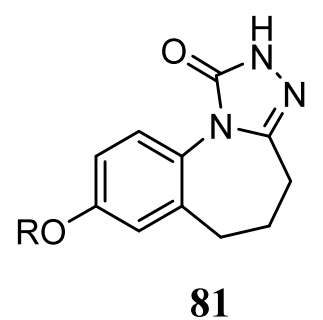

Figure 18. 
<smiles>COS(=O)(=O)c1nnc(-c2ccccc2)n1C</smiles>

82

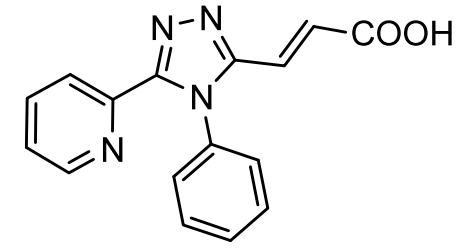

83

Figure 19. 


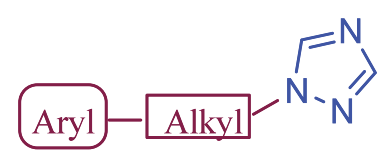

$\mathrm{N}$-(Arylalkyl)triazoles<smiles>C1=CC(n2cncn2)CC1n1cnnc1</smiles>

$\mathrm{N}$-Aryltriazoles<smiles>[X]c1nnc(CC2CCCC2)[nH]1</smiles>

$\mathrm{X}=\mathrm{NH}_{2}, \mathrm{SH}, \mathrm{SR}, \mathrm{OR}$ $\mathrm{n}=0,1$

\section{3,5-Disubstituted-4H-}

1,2,4-triazoles

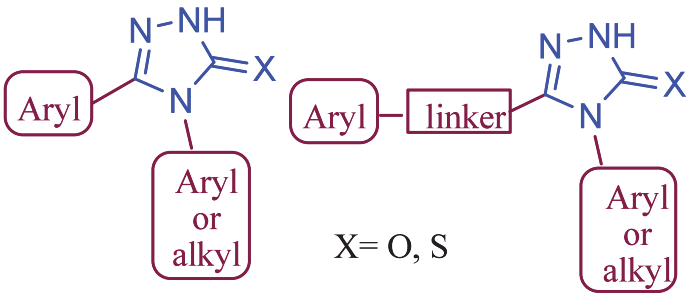

Triazolones and triazole thiones
Lipophilic
substituents<smiles>CC1CCCn2cnnc2C1</smiles><smiles>[R]c1nnc(C2CCCC2)n1[R]</smiles>

Fused-triazoles
Poly substituted triazoles

Figure 20. 